\title{
DZIAŁALNOŚĆ KNP PAN
}

BOGUSŁAW ŚLIWERSKI

Akademia Pedagogiki Specjalnej

im. Marii Grzegorzewskiej w Warszawie

INFORMACJA O DZIAŁALNOŚCI KNP PAN W 2017 ROKU

KOMITET NAUK PEDAGOGICZNYCH PAN

I.1. Skład osobowy i struktura organizacyjna Komitetu:

- prezydium,skład osobowy Komitetu

\section{Prezydium:}

\section{przewodniczacy:}

1. prof. dr hab. Bogusław ŚLIWERSKI - Uniwersytet Łódzki-Wydziat Nauk o Wychowaniu tel.42 66550 85, e-mail: boguslawsliwerski@gmail.com

\section{zastepcy przewodniczacego:}

2. prof. dr hab. Barbara KROMOLICKA - Uniwersytet Szczeciński, Szczecin;

3. prof. dr hab. Dorota KLUS-STAŃSKA - Uniwersytet Gdański, Gdańsk;

4. prof. dr hab. Marek KONOPCZYŃSKI - Uniwersytet w Biatymstoku;

5. prof. dr hab. Stefan KWIATKOWSKI - Akademia Pedagogiki Specjalnej im. Marii Grzegorzewskiej, Warszawa;

6. prof. dr hab. Zbyszko MELOSIK - Uniwersytet im. Adama Mickiewicza, Poznań; 


\section{czlonkowie prezydium:}

7. prof. dr hab. Zenon GAJDZICA - Uniwersytet Ślaski, Katowice-Ciszyn;

8. prof. dr hab. Wiesław JAMROŻEK - Uniwersytet im. Adama Mickiewicza, Poznań;

9. ks. prof. dr hab. Marian NOWAK - Katolicki Uniwersytet Lubelski im. Jana Pawła II, Lublin;

10. prof. dr hab. Mirosław Józef SZYMAŃSKI - Akademia Pedagogiki Specjalnej im. Marii Grzegorzewskiej, Warszawa;

11. prof. dr hab. Władysława SZULAKIEWICZ - Uniwersytet Mikołaja Kopernika, Toruń;

12. prof. dr hab. Amadeusz KRAUSE - Uniwersytet Gdański, Gdańsk;

\section{sekretarz naukowy:}

prof. dr hab. Jerzy NIKITOROWICZ - Uniwersytet $w$ Białymstoku; tel.85 7457001, e-mail: jerzyniki@wp.pl;

\section{Członkowie Komitetu:}

13. prof. dr hab. Krystyna ABLEWICZ - Uniwersytet Jagielloński, Kraków;

14. prof. dr hab. Wiesław AMBROZIK - Uniwersytet im. Adama Mickiewicza, Poznań;

15. prof. dr hab. Ryszard BERA - Uniwersytet Marii Curie-Skłodowskiej, Lublin;

16. prof. dr hab. Agnieszka CYBAL-MICHALSKA - Uniwersytet im. Adama Mickiewicza, Poznań;

17. prof. dr hab. Maria CZEREPANIAK-WALCZAK - Uniwersytet Szczeciński, Szczecin;

18. prof. dr hab. Maria DUDZIKOWA - Uniwersytet im. Adama Mickiewicza, Poznań;

19. prof. dr hab. Roman GERLACH - Uniwersytet Kazimierza Wielkiego w Bydgoszczy, Bydgoszcz;

20. prof. dr hab. Agnieszka GROMKOWSKA-MELOSIK - Uniwersytet im. Adama Mickiewicza, Poznań;

21. prof. dr hab. Krzysztof JAKUBIAK - Uniwersytet Gdański;

22. prof. dr hab. Andrzej RADZIEWICZ-WINNICKI - Społeczna Akademia Nauk w Łodzi;

23. dr hab. Mirosław KOWALSKI, prof. UZ - Uniwersytet Zielonogórski, Zielona Góra; 
24. prof. dr hab. Henryka KWIATKOWSKA - em. prof. Uniwersytetu Warszawskiego, Warszawa;

25. czł. rzecz. PAN Zbigniew KWIECIŃSKI -Uniwersytet Mikołaja Kopernika, Toruń;

26. prof. dr hab. Tadeusz LEWOWCIKI - Honorowy Przewodniczący KNP PAN

27. prof. dr hab. Roman LEPPERT - Uniwersytet Kazimierza Wielkiego w Bydgoszczy, Bydgoszcz;

28. prof. dr hab. Tadeusz PILCH - em. prof. Uniwersytetu Warszawskiego, Warszawa;

29. dr hab. Mirosław SOBECKI prof. UwB - Uniwersytet w Biatymstoku, Biatystok;

30. prof. dr hab. Wiesław THEISS - Akademia Pedagogiki Specjalnej im. Marii Grzegorzewskiej, Warszawa;

31. prof. dr hab. Irena WOJNAR- Honorowy Członek KNP PAN

32. prof. dr hab. Marzenna ZAORSKA - Uniwersytet Warmińsko-Mazurski w Olsztynie, Olsztyn;

\section{Specjaliści:}

1. dr hab. Józefa BAŁACHOWICZ, prof. APS - Akademia Pedagogiki Specjalnej im. Marii Grzegorzewskiej w Warszawie - do prowadzenia Zespołu Edukacji Elementarnej przygotowującego ekspertyzy projektów ustaw oświatowych i rozporządzeń MEN w zakresie edukacji wczesnoszkolnej;

2. dr hab. Ewa BOCHNO, prof. UZ - Uniwersytet Zielonogórski, Zielona Góra - do zainicjowania współpracy KNP PAN ze studenckimi kołami naukowymi pedagogów;

3. dr Radosław NAWROCKI - Uniwersytet im. Adama Mickiewicza, Poznań-Kalisz - do opiniowania aktów prawnych i polityki oświatowej organów władzy centralnej;

4. dr Sławomir PASIKOWSKI - Uniwersytet Łódzki - do ogólnokrajowych konsultacji w zakresie badań empirycznych w naukach o wychowaniu;

5. dr hab. Paweł RUDNICKI prof. DSW - Dolnoślaska Szkoła Wyższa we Wroctawiu - do realizowania zadań związanych z ewaluacją polskich i zagranicznych grantów badawczych w naukach pedagogicznych;

6. dr Agata RZYMEŁKA-FRĄCKIEWICZ - Uniwersytet Ślaski, Katowice do pracy w Sekcji Polityki Oświatowej KNP PAN; 
7. prof. dr hab. BARBARA SMOLIŃSKA-THEISS - Akademia Pedagogiki Specjalnej im. Marii Grzegorzewskiej w Warszawie - do współpracy KNP PAN z Rzecznikiem Praw Dziecka;

8. dr Joanna WIERZEJSKA - Uniwersytet Marii Curie-Skłodowskiej w Lublinie, Lublin - do zadań związanych z monitorowaniem reformy szkolnictwa zawodowego w Polsce;

9. dr Piotr ZAŃKO - Uniwersytet Warszawski - do zadań związanych z diagnozą pedagogiki wobec kultury masowej i popularnej

- komisje,sekcje lub zespoły (nazwy, przewodniczący); udział w ich składzie osób niebędących członkami Komitetu.

\begin{tabular}{|l|l|}
\hline Sekcja ds. nagród, patronatów i konkursów & Przewodniczący: Mirosław J. Szymański \\
& Członkowie Sekcji / Członkowie Komitetu: \\
& 1. Ryszard Bera \\
& 2. Agnieszka Cybal-Michalska \\
& 3. Agnieszka Gromkowska-Melosik \\
& 4. Mirosław Kowalski \\
& 5. Barbara Kromolicka \\
& 6. Stefan Kwiatkowski \\
& 7. Marian Nowak \\
& 8. Sławomir Pasikowski \\
& 9. Wiesław Theiss \\
\hline Sekcja ds. czasopism i wydawnictw & Przewodniczaccy: Bogusław Śliwerski \\
& Członkowie Sekcji / Członkowie Komitetu: \\
& 1. Maria Czerepaniak-Walczak \\
& 2. Maria Dudzikowa \\
& 3. Zenon Gajdzica \\
& 4. Wiesław Jamrożek \\
& 5. Dorota Klus-Stańska \\
& 6. Marek Konopczyński \\
& 7. Mirosław Kowalski \\
& 8. Henryka Kwiatkowska \\
& 9. Roman Leppert \\
& 10. Zbyszko Melosik \\
\hline Sekcja ds. polityki oświatowej & Przewodniczący: Marek Konopczyński \\
& Członkowie Sekcji / Członkowie Komitetu: \\
& 1. Dorota Klus-Stańska \\
& 2. Amadeusz Krause \\
& 3. Radosław Nawrocki \\
& 4. Tadeusz Pilch \\
& 5. Agata Rzymełka-Frąckiewicz \\
& 6. Mirosław Sobecki \\
& 7. Władysława Szulakiewicz \\
& 8. Mirosław J. Szymański \\
& 9. Bogusław Śliwerski \\
& 10. Marzenna Zaorska \\
\hline &
\end{tabular}




\begin{tabular}{|c|c|}
\hline $\begin{array}{l}\text { Sekcja ds. polityki szkolnictwa wyższego } \\
\text { i parametryzacji osiągnięć naukowych }\end{array}$ & $\begin{array}{l}\text { Przewodniczący: Barbara Kromolicka } \\
\text { Członkowie Sekcji / Członkowie Komitetu: } \\
\text { 1. Ryszard Bera } \\
\text { 2. Agnieszka Cybal-Michalska } \\
\text { 3. Zenon Gajdzica } \\
\text { 4. Ryszard Gerlach } \\
\text { 5. Krzysztof Jakubiak } \\
\text { 6. Wiesław Jamrożek } \\
\text { 7. Marek Konopczyński } \\
\text { 8. Amadeusz Krause } \\
\text { 9. Radosław Nawrocki } \\
\text { 10. Jerzy Nikitorowicz } \\
\text { 11. Andrzej Radziewicz-Winnicki } \\
\text { 12. Władysława Szulakiewicz }\end{array}$ \\
\hline Sekcja ds. rozwoju młodych naukowców & $\begin{array}{l}\text { Przewodniczący: Maria Dudzikowa } \\
\text { Członkowie Sekcji / Członkowie Komitetu: } \\
\text { 1. Maria Czerepaniak - Walczak } \\
\text { 2. Zenon Gajdzica } \\
\text { 3. Mirosław Sobecki } \\
\text { 4. Bogusław Śliwerski } \\
\text { 5. Ewa Bochno } \\
\text { 6. Andrzej Radziewicz-Winnicki } \\
\text { 7. Sławomir Pasikowski }\end{array}$ \\
\hline Sekcja ds. informacji & $\begin{array}{l}\text { Przewodniczący: Mirosław Kowalski } \\
\text { Członkowie Sekcji / Członkowie Komitetu: } \\
\text { 1. Agnieszka Cybal-Michalska } \\
\text { 2. Agnieszka Gromkowska-Melosik } \\
\text { 3. Stefan Kwiatkowski } \\
\text { 4. Roman Leppert } \\
\text { 5. Zbyszko Melosik } \\
\text { 6. Andrzej Radziewicz-Winnicki } \\
\text { 7. Bogusław Śliwerski }\end{array}$ \\
\hline $\begin{array}{l}\text { Sekcja ds. wspierania doktorantów i habili- } \\
\text { tantów }\end{array}$ & $\begin{array}{l}\text { Przewodniczący: Zbyszko Melosik } \\
\text { Członkowie Sekcji / Członkowie Komitetu: } \\
\text { 1. Wiesław Ambrozik } \\
\text { 2. Agnieszka Gromkowska-Melosik } \\
\text { 3. Marek Konopczyński } \\
\text { 4. Barbara Kromolicka } \\
\text { 5. Mirosław Kowalski } \\
\text { 6. Roman Leppert } \\
\text { 7. Mirosław Sobecki } \\
\text { 8. Władysława Szulakiewicz } \\
\text { 9. Mirosław J. Szymański } \\
\text { 10. Marzenna Zaorska }\end{array}$ \\
\hline
\end{tabular}




\begin{tabular}{|l|l|}
\hline \multicolumn{2}{|c|}{ DORAŹNE ZESPOŁY ZADANIOWE i PROBLEMOWE przy KNP PAN } \\
\hline Zespół Badania Kultury Szkoły & Przewodniczący: Maria Dudzikowa \\
\hline Zespół Dydaktyki & Przewodnicząca: Dorota Klus-Stańska \\
\hline Zespół Edukacji Elementarnej & $\begin{array}{l}\text { Przewodnicząca: Józefa Bałachowicz - specja- } \\
\text { listka }\end{array}$ \\
\hline Zespół Historii Wychowania & Przewodnicząca: Władysława Szulakiewicz \\
\hline Zespół Edukacji dla Bezpieczeństwa & Przewodniczący: Ryszard Bera \\
\hline Zespół Pedagogiki Chrześcijańskiej & Przewodniczący: x. Marian Nowak \\
\hline $\begin{array}{l}\text { Zespół Pedagogiki Kultury i Edukacji Międzykul- } \\
\text { turowej }\end{array}$ & Przewodniczący: Jerzy Nikitorowicz \\
\hline Zespół Pedagogiki Medialnej i Kultury Popularnej & Przewodniczący: Zbyszko Melosik \\
\hline Zespół Pedagogiki Młodzieży & Przewodnicząca: Agnieszka Cybal-Michalska \\
\hline Zespół Pedagogiki Ogólnej & Przewodniczący: Roman Leppert \\
\hline Zespół Pedagogiki Resocjalizacyjnej & Przewodniczący: Wiesław Ambrozik \\
\hline Zespół Pedagogiki Pracy & Przewodniczący: Stefan Kwiatkowski \\
\hline Zespół Pedagogiki Specjalnej & Przewodnicząca: Marzenna Zaorska \\
\hline Zespół Pedagogiki Społecznej & $\begin{array}{l}\text { Przewodnicząca: Barbara Smolińska-Theiss - } \\
\text { specjalistka }\end{array}$ \\
\hline Zespół Pedeutologii & Przewodnicząca: Henryka Kwiatkowska \\
\hline $\begin{array}{l}\text { Zespół Samokształceniowy i Samopomocy Kole- } \\
\text { zeńskiej Doktorów }\end{array}$ & Przewodniczące: Maria Dudzikowa i Ewa Bochno \\
\hline $\begin{array}{l}\text { Zespół ds. Współpracy ze Studenckimi Kołami Na- } \\
\text { ukowymi }\end{array}$ & Przewodnicząca: Ewa Bochno - specjalistka \\
\hline Zespół Teorii Wychowania & Przewodniczący: Mirosław Kowalski \\
\hline Zespół Metodologii Badań Pedagogicznych & $\begin{array}{l}\text { Przewodniczący: Sławomir Pasikowski - specja- } \\
\text { lista }\end{array}$ \\
\hline
\end{tabular}

\section{I.2. Zakres działania Komitetu}

Analiza i ocena rozwoju nauk pedagogicznych w Polsce oraz kształcenia kadr w zakresie pedagogiki i na kierunkach nauczycielskich; diagnozowanie stanu oświaty i szkolnictwa wyższego oraz nauki; przygotowywanie ekspertyz dla rządu i organizacji pozarządowych a dotyczących działań reformatorskich resortów edukacji, szkolnictwa wyższego i nauki; opracowywanie nowych koncepcji i propozycji rozwiązań modelowych dotyczących oświaty, kształcenia i doskonalenia kadr naukowych w dziedzinie pedagogiki oraz kształcenia nauczycieli. Komitet został powołany w $1953 \mathrm{r}$. 


\section{ZEBRANIA KOMITETU (OPIS)}

\section{II.1. Zebrania plenarne (data, najważniejsze omawiane problemy, w tym ze- brania z referatami naukowymi).}

\begin{tabular}{|c|c|}
\hline \multicolumn{2}{|l|}{ Rok 2017} \\
\hline Problematyka & $\begin{array}{c}\text { Miejsce i data posie- } \\
\text { dzenia }\end{array}$ \\
\hline $\begin{array}{l}\text { Problematyka posiedzenia KNP PAN: „Bilans zamknięcia“ - efektów funkc- } \\
\text { jonujacych po reformie M. Handke szkót ogólnodostępnych. Analiza wyniki } \\
\text { ostatnich badań PISA dotyczących osiągnięć szkolnych piętnastolatków. Co } \\
\text { warte były gimnazja, które są likwidowane? } \\
\text { Prezentacje: } \\
\text { POLSKA OŚWIATA W BADANIACH MIĘDZYNARODOWYCH (dr hab. } \\
\text { Michał Federowicz, dr Michał Sitek) } \\
\text { JAKOŚĆ KSZTAŁCENIA - PRZEDMIOTY OGÓLNOKSZTALCĄCE (dr } \\
\text { hab. Krzysztof Biedrzycki, mgr Michał Karpiński) } \\
\text { Prowadzący - prof. dr hab. Mirosław J. Szymański } \\
\text { II część - Sprawy organizacyjno-programowe KNP PAN }\end{array}$ & $\begin{array}{l}10 \text { kwietnia } 2017 \\
\text { roku Instytut Badań } \\
\text { Edukacyjnych, ul. } \\
\text { Górczewska 8; War- } \\
\text { szawa. }\end{array}$ \\
\hline $\begin{array}{l}\text { Problematyka posiedzenia KNP PAN: Współczesna pedagogika wobec dydak- } \\
\text { tyk przedmiotowych i kształcenia nauczycieli przedmiotów. } \\
\text { Otwarcie posiedzenia: Prof. dr hab. Bogusław Śliwerski - Przewodniczący } \\
\text { KNP PAN } \\
\text { Kształcenie nauczycieli przedmiotowych - debata } \\
\text { wprowadzenie: prof. dr hab. Dorota Klus-Stańska } \\
\text { Referaty: } \\
\text { Prof. dr hab. Amadeusz Krause: Kształcenie nauczycieli w obecnej sytuacji } \\
\text { prawnej - diagnoza problemów i propozycje rozwiazań } \\
\text { Prof. dr hab. Bogusław Śliwerski: Awanse naukowe (zawodowe) nauczycieli } \\
\text { w świetle nowelizacji ustawy o doktoratach branżowych } \\
\text { Prof. dr hab. Stefan Kwiatkowski: Kształcenie, dokształcanie i doskonalenie } \\
\text { nauczycieli szkót zawodowych } \\
\text { Prof. dr hab. Dorota Klus-Stańska: Czego uczą się przyszli polscy nauczyciele? } \\
\text { Część II: Bieżące sprawy KNP } \\
\text { Uchwała o powołaniu subdyscyplinarnego Zespołu Metodologii Badań Peda- } \\
\text { gogicznych Komitetu Nauk Pedagogicznych PAN - przewodniczący: dr Sła- } \\
\text { womir Pasikowski }\end{array}$ & $\begin{array}{l}5 \text { czerwca } 2017 \text { r., } \\
\text { Warszawa (PAN - } \\
\text { Pałac Staszica) }\end{array}$ \\
\hline $\begin{array}{l}\text { Problematyka posiedzenia KNP PAN z udziałem rektorów uczelni pedago- } \\
\text { gicznych i dziekanów uniwersyteckich wydziałów pedagogicznych / edukacyj- } \\
\text { nych: PEDAGOGIKA UNIWERSYTECKA WOBEC PROJEKTOWANYCH } \\
\text { ZMIAN W USTROJU SZKOLNICTWA WYŻSZEGO W POLSCE } \\
\text { Wręczenie przez inicjatora wyróżnienia, wiceprzewodniczącego KNP PAN - } \\
\text { prof. dr. hab. Marka Konopczyńskiego „Medalu Za Zasługi Dla Rozwoju Pol- } \\
\text { skiej Pedagogiki” - Profesorowi Jerzemu Niemcowi } \\
\text { Część naukowa posiedzenia: } \\
\text { Miejsce i rola uniwersytetu w świetle zmian społecznych i politycznych zacho- } \\
\text { dzących w Polsce: } \\
\text { Przewodniczący obrad: prof. dr hab. Bogusław Śliwerski, prof. dr hab. Jerzy } \\
\text { Nikitorowicz }\end{array}$ & $\begin{array}{l}\text { 23-24.10.2017 Wy- } \\
\text { dział Pedagogiki } \\
\text { i Psychologii Uni- } \\
\text { wersytetu w Białym- } \\
\text { stoku }\end{array}$ \\
\hline
\end{tabular}


prof. dr hab. Zbyszko Melosik - Tożsamość uniwersytetu w kulturze niepewności.

prof. dr hab. Barbara Kromolicka - Po Kongresie Nauki Polskiej w Krakowie Sytuacja pedagogiki jako nauki w kontekście proponowanych zmian ustroju szkolnictwa wyższego w Polsce

Przewodniczący obrad: prof. dr hab. Stefan M. Kwiatkowski,, prof. dr hab. Zbyszko Melosik

prof. dr hab. Roman Leppert - Pedagogika (jako dyscyplina naukowa i kierunek studiów) w świetle proponowanej ustawy Prawo o szkolnictwie wyższym PEDAGOGIKA U PROGU ZMIAN - DEBATA

Przewodniczenie obradom: prof. dr hab. Marek Konopczyński, prof. dr hab. Stefan M. Kwiatkowski

Wprowadzenie - prof. dr hab. Bogusław Śliwerski - Ustawa 2.0 - i jej implikacje dla awansów naukowych z pedagogiki

Rektorzy Uczelni, Dziekani Wydziałów oraz Dyrektorzy Instytutów Nauk Pedagogicznych o problemach i oczekiwaniach ich środowisk w związku z reformą 2.0

Wprowadzenie: prof. dr hab. Stefan M. Kwiatkowski

Przewodniczenie obradom: prof. dr hab. Barbara Kromolicka

Pedagogika uniwersytecka wobec odpowiedzialności za realizację standardów kształcenia pedagogicznego i nauczycielskiego

Prof. dr hab. Bożena Muchacka: Kształcenie nauczycieli na kierunkach pedagogicznych - diagnoza problemu z perspektywy PKA.

Dr hab. Krystyna Ablewicz (UJ) - Kompetencje relacyjne pedagoga - teoretyczne i empiryczne uzasadnienia potrzeby ich posiadania

Problematyka posiedzenia KNP PAN: Debata poświęcona skutkom reformy oświatowej dla wsi, szkoły i dziecka wiejskiego.

Wręczenie przez inicjatora wyróżnienia, wiceprzewodniczącego KNP PAN prof. dr. hab. Marka Konopczyńskiego „Medalu Za Zasługi Dla Rozwoju Polskiej Pedagogiki” - Profesorom: Bogdanowi Szczepankowskiemu i Karolowi Poznańskiemu.

Część naukowa posiedzenia:

Panel dyskusyjny z udziałem zaproszonych samorządowców i liderów ruchów obywatelskich na rzecz wspierania małych szkól:

Prowadzenie: prof. dr hab. Tadeusz Pilch. Uczestnicy panelu: wójt Gminy Hanna (woj. lubelskie), Pani Grażyna Kowalik; wójt Gminy Długosiodło (woj. mazowieckie), Pan Stanisław Jastrzębski; wójt Gminy Iłowo-Osada (woj. warmińsko -mazurskie), Pan Sebastian Cichocki; Prezes Federacji Inicjatyw Oświatowych: Pani Małgorzata Lewandowska i Pani Alina Kozińska-Bałdyga, liderka ruchu Rodzice Przeciwko Reformie, Pani Dorota Łoboda, Prezes Stowarzyszenia Pomocy Pokrzywdzonym i Niepełnosprawnym „Edukator”, Pani Barbara Kuczałek, oraz Pani dr Elżbieta Chojnowska.

Część organizacyjna:

Informacja o ponowieniu przez KNP PAN wniosku o Nagrodę PRM dla prof. dr hab. Alicji Kargulowej, który został przyjęty przez KNP PAN w czerwcu $2017 \mathrm{r}$.
23-24.10.2017 Wydział Pedagogiki i Psychologii Uniwersytetu w Białymstoku
Warszawa, 11 grudnia 2017 r. PAN (PKiN) 
III. POSIEDZENIA KOMISJI, SEKCJI, ZESPOŁÓW

(LICZBA, W TYM POSIEDZENIA Z REFERATAMI NAUKOWYMI)

\section{Działalność DORAŹNYCH ZESPOLÓW SUBDYSCYPLINARNYCH i PROBLEMOWYCH}

Sekcja ds. wspierania doktorantów i habilitantów - 20 maja 2016 roku odbyło się seminarium pt. „Problemy rozwoju i awansu młodych naukowców - wybrane konteksty i perspektywy (Wydziat Studiów Edukacyjnych UAM). W seminarium wzięło udział ponad 60 pracowników nauki z 22 jednostek naukowych posiadających uprawnienia do nadawania co najmniej stopnia naukowego doktora z zakresu pedagogiki.

Sekcja ds. polityki oświatowej - przygotowanie opinii projektów ustaw oświatowych i rozporządzeń MEN w zakresie polityki oświatowej.

Sekcja ds. polityki szkolnictwa wyższego i parametryzacji osiągnięć na-

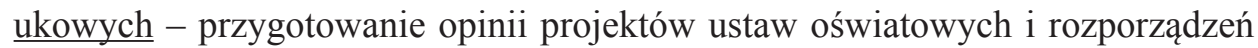
MNiSzW w zakresie polityki szkolnictwa wyższego i parametryzacji osiągnięć naukowych. Projekty dotyczyły m.in.: ustawy o zmianie ustawy o stopniach naukowych i tytule naukowym oraz o stopniach i tytule w zakresie sztuki oraz niektórych innych ustaw; doktoratu wdrożeniowego; ustawy deregulacyjnej MNiSW; rozporządzeń zmieniających rozporządzenia w sprawie nagród ministra dla nauczycieli akademickich; w sprawie nagród za wybitne osiągnięcia naukowe oraz za osiągnięcia w opiece naukowej i dydaktycznej; w sprawie przyznawania kategorii naukowej jednostkom naukowym oraz projektu sposobu podziału dotacji dla uczelni publicznych na zadania związane z kształceniem studentów studiów stacjonarnych, kształceniem uczestników stacjonarnych studiów doktoranckich, kształceniem kadr naukowych i utrzymaniem uczelni, w tym na remonty.

Sekcja ds. informacji KNP PAN - wydawca Elektronicznego Biuletynu Komitetu Nauk Pedagogicznych Polskiej Akademii Nauk. W roku 2017 rozpowszechniła 35 numerów biuletynu (każdy numer wysyłany jest do prawie 2000 pracowników naukowo-dydaktycznych).

Zespół Pedagogiki Resocjalizacyjnej działał w 2017 r. w niezmienionym zasadniczo składzie osobowym. Kierowało nim prezydium: Prof. dr hab. Wiesław Ambrozik (UAM w Poznaniu)) - przewodniczący, Prof. dr hab. Marek Konopczyński (Uniwersytet w Białymstoku) - wiceprzewodniczący, Prof. dr hab. Beata Pastwa - Wojciechowska (Uniwersytet Gdański), Prof. dr hab. Andrzej Bałandynowicz (WSP w Warszawie), dr hab., Sławomir Przybyliński, prof. UWM w Olsztynie) - członkowie prezydium, oraz dr hab. Maciej Muskała (UAM w Poznaniu)- sekretarz Zespołu. Działalność zespołu w minionym okresie koncentrowała się zgodnie z przyjętymi założeniami na trzech obszarach: wydawniczym, samokształceniowym i promocyjnym. W obszarze działalności wydawniczej Zespół 
sprawował patronat nad ukazującym się regularnie półroczniku Resocjalizacja Polska - jedynym w naszym kraju wysoko punktowanym (12 pkt.) czasopiśmie naukowym, poświęconym współczesnym problemom resocjalizacji, profilaktyki społecznej i readaptacji osób wykolejonych społecznie - finansowanym przez Ministerstwo Nauki i Szkolnictwa Wyższego. W minionym roku m.in. z inicjatywy Zespołu doprowadzono do podpisania umowy o współpracy wydawniczej w Wydziałem Studiów Edukacyjnych UAM. Tym samym od bieżącego roku wydawcą niniejszego czasopisma będzie zarówno Fundacja Pedagogium, jak i Wydziala Studiów Edukacyjnych UAM., co gwarantować będzie zarówno jego niezmienny wysoki poziom naukowy, jak i bezpieczeństwo finansowania kosztów wydawniczych w perspektywie ewentualnych zmian ustawowych. $\mathrm{Na}$ podkreślenie zasługuje fakt, że czasopismo wydawane jest w wersji dwujęzycznej (polskiej i angielskiej) i jest afiliowane w kilku znaczących bazach zagranicznych, a od 2018 roku jego podstawową formą będzie wersja cyfrowa. Przewodniczącym Rady Naukowej pisma jest Prof. zw. dr hab. Wiesław Ambrozik a Redaktorem Naczelnym - prof. zw. dr hab. Marek Konopczyński, natomiast członkowie Zespołu wchodzą w skład Redakcji i Rady Naukowej. W ramach działalności samokształceniowej w dalszym ciągu działa Koło Młodych Pracowników Naukowych, zajmujące się organizowaniem spotkań, seminariów i konferencji naukowych poświęconych prezentowaniu osiągnięć merytorycznych jego członków. Wprawdzie w ostatnim czasie aktywność Koła nieco spowolniła swoją aktywność, a dawne spotkania zespołowe przybrały postać indywidualnych konsultacji naukowych, to jednak planuje się powrócić do pierwotnych spotkań seminaryjnych, realizowanych za pośrednictwem łączy elektronicznych, organizowanych w wiodących ośrodkach pedagogiki resocjalizacyjnej. Profesorowie skupieni w Zespole aktywnie udzielali konsultacji młodszym pracownikom naukowym w zakresie projektowanych przez nich rozpraw habilitacyjnych, a także uczestniczyli w procedurach awansowych z obszaru pedagogiki resocjalizacyjnej.

Działalność merytoryczna i promocyjna Zespołu związana była głównie z aktywnym uczestnictwem jego członków w rozmaitych gremiach eksperckich m.in. Ministerstwa Sprawiedliwości, Ministerstwa Edukacji Narodowej, Biura Rzecznika Praw Obywatelskich, Biura Rzecznika Praw Dziecka, Komendy Głównej Policji, Centralnego Zarządu Służby Więziennej, Krajowej Rady Kuratorów, itp. Warto podkreślić, że Przewodniczący Zespołu Pedagogiki Resocjalizacyjnej przy KNP PAN - Prof. zw. dr hab. Wiesław Ambrozik pełni funkcję Wiceprzewodniczącego Rady Polityki Penitencjarnej przy Ministrze Sprawiedliwości, natomiast jego Wiceprzewodniczący - prof. zw. dr hab. Marek Konopczyński jest Wiceprzewodniczącym Rady Głównej ds. Społecznej Readaptacji i Pomocy Skazanym w tym samym Ministerstwie oraz społecznym doradcą Rzecznika Praw Dziecka. 
Zespół Pedagogiki Resocjalizacyjnej patronował w minionym okresie kilku konferencjom i seminariom naukowym organizowanym przez ośrodki akademickie w Polsce. Warto wymienić tu wielce znaczące zarówno dla członków Zespołu jak i całego środowiska naukowego pedagogów resocjalizacyjnych seminarium naukowe: Resocjalizacja, readaptacja, reintegracja- spoleczny teatr pozorów poświęcone węzłowym problemom współczesnej pedagogiki resocjalizacyjnej, zorganizowane w Goniądzu przez Katedrę Pedagogiki Specjalnej Wydziału Pedagogiki i Psychologii Uniwersytetu w Białymstoku. Jego uczestnikami byli przedstawiciele wszystkich znaczących naukowo ośrodków akademickich prowadzących studia z zakresu pedagogiki resocjalizacyjnej oraz liczne grono wybitnych praktyków (głównie kuratorów sądowych i pracowników zakładów resocjalizacyjnych) - członków Zespołu.

Zespół Pedagogiki Specjalnej - Przewodnicząca: prof. dr hab. Marzenna Zaorska. Liczba osób uczestniczących w pracach Zespołu a niebędących członkami KNP PAN: 59; liczba odbytych posiedzeń: 3.

\begin{tabular}{|l|c|l|c|}
\hline Miejsce posiedzenia & Data & \multicolumn{1}{|c|}{ Problematyka/tematyka } & Liczba uczestników \\
\hline UAM w Poznaniu & 13.03 .2017 r. & $\begin{array}{l}\text { Pedagogika specjalna jako subdyscy- } \\
\text { plina pedagogiki czy samodzielna dys- } \\
\text { cyplina naukowa? }\end{array}$ & 43 \\
\hline $\begin{array}{l}\text { WSGGW w Warsza- } \\
\text { wie }\end{array}$ & 19.06 .2017 r. & $\begin{array}{l}\text { 1. Dylemat seksualności osób z nie- } \\
\text { pełnosprawnością w kontekście teore- } \\
\text { tycznym i praktycznym. } \\
\text { 2. Kształcenie na kierunku pedagogi- } \\
\text { ka specjalna jakość kształcenia, do- } \\
\text { świadczenia, problemy, osiągnięcia, } \\
\text { niedociągnięcia, możliwości modyf- } \\
\text { kacji). }\end{array}$ & 41 \\
\hline UKW w Bydgoszczy & $6.11 .2017 \mathrm{r}$. & $\begin{array}{l}\text { 1. Samotroska opiekunów nieformal- } \\
\text { nych osób chorych przewlekle i nie- } \\
\text { pełnosprawnych. 2. Standardy kształ- } \\
\text { cenia nauczycieli w perspektywie } \\
\text { Ustawy 2.0. }\end{array}$ \\
\hline
\end{tabular}

Zespół Dydaktyki - zespół zadaniowy. Przewodnicząca - prof. zw. dr hab. Dorota Klus-Stańska.

Liczba osób uczestniczących w pracach Zespołu a niebędących członkami KNP PAN: 11 ( 9 - liczba członków, którzy podjęli się realizacji zadań cząstkowych); liczba odbytych posiedzeń 4 , w tym jedno dwudniowe. Wszystkie posiedzenia miały charakter roboczy, związany z przyjętymi zadaniami. Członkowie Zespołu, którzy przyjęli na siebie zadania cząstkowe prezentowali na nich postęp prac i poddawali je pod dyskusję oraz dalsze planowanie. 


\begin{tabular}{|c|c|c|c|}
\hline $\begin{array}{c}\text { Miejsce } \\
\text { posiedzenia }\end{array}$ & Data & $\begin{array}{c}\text { Liczba } \\
\text { uczestników }\end{array}$ & Problematyka/tematyka \\
\hline Gdańsk & $\begin{array}{l}23 \text { stycznia } \\
2017\end{array}$ & 7 & \multirow{4}{*}{$\begin{array}{l}\text { Zadania przyjęte do wykonania: } \\
\text { 1) Opracowanie nowego dwutomowego podręcznika } \\
\text { dydaktyki: Dydaktyka. Podręcznik akademicki; } \\
\text { 2) Nawiązanie współpracy dydaktyków ogólnych } \\
\text { z dydaktykami szczegółowymi. W jej ramach } \\
\text { zorganizowanie cyklu Seminariów Naukowych } \\
\text { Dydaktyk Szczegółowych; } \\
\text { 3) Przygotowanie publikacji podejmującej proble- } \\
\text { my dydaktyk szczegółowych - „,Forum Oświato- } \\
\text { we”, numer zaakceptowany; } \\
\text { 4) Przygotowanie antologii „Wybór XX-wiecznych } \\
\text { koncepcji dydaktycznych”. }\end{array}$} \\
\hline $\begin{array}{l}\text { Poznań } \\
\text { (dwudniowe) }\end{array}$ & $\begin{array}{l}\text { 24-25 kwiet- } \\
\text { nia } 2017\end{array}$ & 8 & \\
\hline Gdańsk & 21 maja 2017 & 7 & \\
\hline Gdańsk & $\begin{array}{l}30 \text { paździer- } \\
\text { nika } 2017\end{array}$ & 8 & \\
\hline
\end{tabular}

Wykaz działań w ramach zadań Zespołu (ekspertyzy, opinie, stanowiska, itp.): 1) D. Klus-Stańska, Uwagi do Podstawy programowej ksztatcenia ogólnego dla szkoty podstawowej;

2) D. Klus-Stańska, Uwagi do projektu Podstawy programowej wychowania przedszkolnego dla przedszkoli, oddziałów przedszkolnych w szkołach podstawowych oraz innych form wychowania przedszkolnego.

Wykaz publikacji, artykułów, wywiadów, sprawozdań itp. będących wynikiem prac Zespołu:

1) Klus-Stańska D., Dydaktyka. Podręcznik akademicki, złożony do druku.

Szyling G. (2017), „Sprawozdanie z Ogólnopolskiego Seminarium Naukowego Dydaktyk Szczegółowych: „Wokół pytań o naukowy status dydaktyk szczegółowych”, Gdańsk, 21-22 maja 2017. „Forum Oświatowe”, 29(1), 229-232. Pobrano z: http://forumoswiatowe.pl/index.php/czasopismo/article/view/542.

Szyling G., Redakcja sekcji tematycznej w „Forum Oświatowym” poświęconej dydaktykom szczegółowym; numer zaakceptowany.

4) Groenwald M., O naukowym statusie dydaktyków przedmiotowych. Gtos $w$ dyskusji, „Forum Oświatowe”, w recenzji.

Zespół Historii Wychowania przy KNP PAN; Przewodnicząca - prof. dr hab. Władysława Szulakiewicz; Sekretarz: dr Joanna Falkowska. Liczba osób uczestniczących w pracach Zespołu a niebędących członkami KNP PAN: 43. Systematyczną współpracę z Zespołem Historii Wychowania przy KNP PAN w roku 2017 podjęło 46 członków Zespołu, w tym 43 niebędących członkami KNP. Natomiast współpracę przejawiającą się głównie udziałem w konferencjach i seminariach naukowych około 60 osób. Liczba odbytych posiedzeń Posiedzenia ZHW odbywają się w terminach konferencji i seminariów. W każdym roku odbywa się jedno posiedzenie robocze (zazwyczaj w miesiącu październiku lub grudniu), którego celem jest dyskusja nad planem działania na kolejny rok, a głównie ustalenie tematyki i organizatorów konferencji i seminariów naukowych. 
Odbyły się dwa spotkania naukowe: Seminarium w Obrzycku w dniu 28.06.2017 roku pt. „Gromadzenie i ochrona źródeł szkolnych” oraz Ogólnopolska Konferencja Naukowa pt. „Wielkopolska i Wielkopolanie w dziejach edukacji” zorganizowana z okazji Jubileuszu 50-lecia Zakładu Historii Wychowania WSE UAM w Poznaniu, 25-26.09.2017 r. Częściowo informacje o publikacjach członków ZHW przy KNP PAN są na stronie Zespołu http://www.home.umk.pl/ khmpwnp/. Szczegółowe informacje na temat publikacji w moim posiadaniu i sekretarza ZHW dr J. Falkowskiej. Efektem zbiorowej współpracy członków Zespołu w roku 2017 są 2 książki, które są w druku: 1) Nauczyciele. Szkice portretów uczonych i nauczycieli pod red. Anny Królikowskiej i Joanny Falkowskiej, Kraków 2018. 2) Nauczyciele. Zastużeni-niedocenieni- zapamiętani, pod red. Władysławy Szulakiewicz, Toruń 2018. Ponadto opublikowane sprawozdanie z konferencji: J. Falkowska, Sprawozdanie z konferencji naukowej nt. Nauczyciele. Zastużeni - niedocenieni - zapamiętani, „Przegląd Historyczno-Oświatowy” 2017, nr 3-4, s. 229-232. Poza tym sprawozdanie ukaże się w „Biuletynie Historii Wychowania”.

ZESPÓ£ PEDAGOGIKI KULTURY I EDUKACJI MIĘDZYKULTUROWEJ - Przewodniczący: prof. dr hab. JERZY NIKITOROWICZ - Uniwersytet w Białymstoku. Liczba osób uczestniczących w pracach Zespołu a niebędących członkami KNP PAN: 68; liczba odbytych posiedzeń: 1

\begin{tabular}{|c|c|c|c|}
\hline $\begin{array}{c}\text { Miejsce } \\
\text { posiedzenia }\end{array}$ & Data & Problematyka/tematyka & $\begin{array}{c}\text { Liczba } \\
\text { uczestników }\end{array}$ \\
\hline $\begin{array}{l}\text { Hotel Austeria } \\
\text { w Ciechocinku }\end{array}$ & 26.04 .2017 & $\begin{array}{l}\text { 1. Powołanie Grup Studyjnych działających w ra- } \\
\text { mach Zespołu Pedagogiki Kultury i Edukacji Mię- } \\
\text { dzykulturowej KNP PAN. Powołane grupy studyj- } \\
\text { ne to: } \\
\text { - GRUPA STUDYJNA DS. ANIMACJI KULTU- } \\
\text { RY, koordynator: prof. dr hab. Dariusz Kubinow- } \\
\text { ski, Uniwersytet Szczeciński } \\
\text { - GRUPA STUDYJNA DS. PRZESTRZENI } \\
\text { EDUKACJI MIĘDZYKULTUROWEJ, koor- } \\
\text { dynator: prof. dr hab. Alicję Szerląg, Uniwersytet } \\
\text { Wrocławski } \\
\text { - GRUPA STUDYJNA DS. EDUKACJI GLO- } \\
\text { BALNEJ, koordynator: dr Ewa Pająk-Ważna - } \\
\text { Uniwersytet Pedagogiczny w Krakowie } \\
\text { - GRUPA STUDYJNA DS. INTEGRACJI SPO- } \\
\text { LECZNEJ ROMÓW, koordynatorzy: dr Łukasz } \\
\text { Kwadrans, Uniwersytet Śląski w Katowicach i Je- } \\
\text { rzy Grzegorek, Uniwersytet Szczeciński } \\
\text { - GRUPA STUDYJNA DS. EDUKACJI DZIECI } \\
\text { Z GRUP MNIEJSZOŚCIOWYCH I RELIGIJ- } \\
\text { NYCH, koordynator: dr hab. prof. PWSZ Beata } \\
\text { Anna Orłowska, PWSZ im. Jakuba z Paradyża } \\
\text { w Gorzowie Wielkopolskim }\end{array}$ & 44 \\
\hline
\end{tabular}


- GRUPA STUDYJNA DS. DIALOGU I TOLERANCJI - zgłoszona przez prof. dr hab. Tadeusza Pilcha, Zespół Pedagogiki Społecznej KNP PAN

- GRUPA STUDYJNA DS. EDUKACJI REGIONALNEJ - zgłoszona przez dr. hab. prof. UMK, Piotra Petrykowskiego, Uniwersytet Mikołaja Kopernika w Toruniu (koordynatorzy: dr Alina Szwarc, Uniwersytet w Białymstoku; dr Joanna Cukras-Stelągowska, Uniwersytet Mikołaja Kopernika w Toruniu)

- GRUPA STUDYJNA DS. SZKOLNICTWA I SZKÓŁ Z POLSKIM JĘZYKIEM NAUCZANIA - zgłoszona przez prof. dr hab. Ewę Ogrodzką-Mazur, Uniwersytet Śląski w Katowicach

- GRUPA STUDYJNA DS. KOMPETENCJI MIĘDZYKULTUROWYCH - zgłoszona przez dr. hab., prof. UMCS, Mariusza Korczyńskiego, Uniwersytet Marii Curie-Skłodowskiej w Lublinie

- GRUPA STUDYJNA DS. PORADNICTWA MIĘDZYKULTUROWEGO - zgłoszona przez prof. zw. dr hab. Alicję Kargul, Dolnośląska Szkoła Wyższa (2 spotkania grupy: styczeń, maj 2017, miejsce: Dolnośląska Szkoła Wyższa we Wrocławiu, problematyka spotkań: Identyfikacja problemów, działań, procesów poradniczych w „Chłopie polskim w Europie i w Ameryce" - W. Thomasa i F. Znanieckiego)

- GRUPA STUDYJNA DS. REPARTIACJI POLAKÓW

Kierunki rozwoju ZPKiEM - plany merytoryczne, organizacyjne. Tworzenie zbiorów publikacji z zakresu pedagogiki kultury i edukacji międzykulturowej

Bieżące informacje o konferencjach organizowanych przez ośrodki, których przedstawiciele są członkami Zespołu PKiEM

Sprawy bieżące i wnioski (propozycja seminariów doktorskich i podoktorskich w ramach Zespołu oraz propozycja tygodni międzykulturowych organizowanych w poszczególnych ośrodkach badawczych Członków ZPKiEM. Tydzień międzykulturowy to forma edukacji nauczycieli akademickich, jak również prezentacja dorobku naukowego danego ośrodka oraz dziedzictwa kulturowego regionu, w którym jest położony. Ta inicjatywa miałaby być formą promocji prowadzonych badań i upowszechniania edukacji międzykulturowej jako istotnego elementu kształcenia obecnych i przyszłych pedagogów). 
Zespół Pedagogiki Ogólnej - Przewodniczący: prof. dr hab. Roman Leppert; Liczba osób uczestniczących w pracach Zespołu a niebędących członkami KNP PAN: 30 osób; liczba odbytych posiedzeń: 2

\begin{tabular}{|l|c|l|c|}
\hline \multicolumn{1}{|c|}{$\begin{array}{c}\text { Miejsce } \\
\text { posiedzenia }\end{array}$} & Data & \multicolumn{1}{c|}{ Problematyka/tematyka } & $\begin{array}{c}\text { Liczba } \\
\text { uczestników }\end{array}$ \\
\hline $\begin{array}{l}\text { UKSW } \\
\text { Warszawa }\end{array}$ & 21.04 .2017 r. & Nieafirmatywna koncepcja pedagogiki ogólnej & 19 osób \\
\hline $\begin{array}{l}\text { Uniwersytet Wro- } \\
\text { cławski }\end{array}$ & 27.09 .2017 r. & $\begin{array}{l}\text { Polskie koncepcje pedagogiki ogólnej w ujęciu } \\
\text { porównawczym }\end{array}$ & 27 osób \\
\hline
\end{tabular}

Zespół Metodologii Badań Pedagogicznych. Przewodniczący: dr Sławomir Pasikowski. Liczba osób uczestniczących $\mathrm{w}$ pracach Zespołu a niebędących członkami KNP PAN: 38; liczba odbytych posiedzeń: 2.

\begin{tabular}{|c|c|c|c|}
\hline $\begin{array}{c}\text { Miejsce } \\
\text { posiedzenia }\end{array}$ & Data & Problematyka/tematyka & $\begin{array}{c}\text { Liczba } \\
\text { uczestników }\end{array}$ \\
\hline $\begin{array}{l}\text { Wydział Nauk } \\
\text { Pedagogicznych } \\
\text { Uniwersytetu Mi- } \\
\text { kołaja Kopernika } \\
\text { w Toruniu }\end{array}$ & $\begin{array}{l}17 \text { maja } \\
2017\end{array}$ & $\begin{array}{l}\text { Posiedzenie inauguracyjne, przyjęcie projektu } \\
\text { struktury, celów i zadań zespołu }\end{array}$ & 21 \\
\hline $\begin{array}{l}\text { Wydział Studiów } \\
\text { Edukacyjnych, } \\
\text { Uniwersytet im. } \\
\text { Adama Mickiewi- } \\
\text { cza w Poznaniu }\end{array}$ & $\begin{array}{l}14 \text { grudnia } \\
2017\end{array}$ & $\begin{array}{l}\text { Kształcenie metodologiczne na studiach pedago- } \\
\text { gicznych }\end{array}$ & 21 \\
\hline
\end{tabular}

Zespół Samokształceniowy i Samopomocy Koleżeńskiej Doktorów. Przewodniczące Prof. zw. dr hab. Maria Dudzikowa i dr hab. Ewa Bochno, prof. UZ. Liczba osób uczestniczących w pracach Zespołu, a niebędących członkami KNP PAN: 53 osoby, liczba odbytych posiedzeń: wszystkich: w latach 2009-2017 32. W roku 2017 - ze względu na chorobę Przewodniczącej Zespołu, odbyło się jedno Ogólnopolskie Seminarium Naukowe Zespołu oraz liczne konsultacje indywidualne lub w małych grupach zarówno członkiń oraz członków Zespołu z Przewodniczącymi, jak i między sobą.

Zespół Pedagogiki Młodzieży. Przewodnicząca: prof. zw. dr hab. Agnieszka Cybal-Michalska. Liczba osób uczestniczących w pracach Zespołu a niebędących członkami KNP PAN: 112 osób niebędących członkami KNP PAN i 7 członków KNP PAN. W 2017 r. odbyły się 3 posiedzenia: 


\begin{tabular}{|c|c|c|c|}
\hline $\begin{array}{c}\text { Miejsce } \\
\text { posiedzenia }\end{array}$ & Data & Problematyka/tematyka & $\begin{array}{c}\text { Liczba } \\
\text { uczestników }\end{array}$ \\
\hline $\begin{array}{l}\text { Wydział Studiów Edu- } \\
\text { kacyjnych Uniwersytetu } \\
\text { im. Adama Mickiewicza } \\
\text { w Poznaniu }\end{array}$ & 28.02 .2017 & $\begin{array}{l}\text { Prowadzenie dyskursu na temat młodzieży } \\
\text { jako przedmiocie (młodzież w centrum pe- } \\
\text { dagogiki) i podmiocie (młodzież w centrum } \\
\text { permanentnej zmiany społecznej) badań } \\
\text { pedagogicznych. Ideą przewodnią niniej- } \\
\text { szego spotkania był temat wykładu Prof. } \\
\text { zw. dr hab. Zbyszko Melosika - Zastępcy } \\
\text { Przewodniczącego KNP PAN: Spoteczne } \\
\text { konstrukcje młodzieży: metamorfozy tożsa- } \\
\text { mości }\end{array}$ & 86 \\
\hline $\begin{array}{l}\text { Wydział Studiów Edu- } \\
\text { kacyjnych Uniwersytetu } \\
\text { im. Adama Mickiewicza } \\
\text { w Poznaniu }\end{array}$ & 30.05 .2017 & $\begin{array}{l}\text { Wykład prof. UJ dr hab. Marka Kucia z Za- } \\
\text { kładu Socjologii Wiedzy Instytutu Socjo- } \\
\text { logii Uniwersytetu Jagiellońskiego w Kra- } \\
\text { kowie, pt.: Pamięć zbiorowa młodzieży? } \\
\text { Uwagi teoretyczne i metodologiczne } \\
\text { Powołanie Zespołów Roboczych działają- } \\
\text { cych w ramach Zespołu Pedagogiki Mło- } \\
\text { dzieży }\end{array}$ & 106 \\
\hline $\begin{array}{l}\text { Wydział Nauk Stosowa- } \\
\text { nych Wyższej Szkoły } \\
\text { Biznesu w Dąbrowie } \\
\text { Górniczej }\end{array}$ & 27.10 .2017 & $\begin{array}{l}\text { Wykład Prof. dr. hab. Witolda Jakubowskie- } \\
\text { go z Uniwersytetu Wrocławskiego: Kultura } \\
\text { popularna, media i społeczeństwo, czyli kil- } \\
\text { ka refleksji o partycypacji w kulturze } \\
\text { Wartościowa Godzina z Zespołem Robo- } \\
\text { czym - prezentacja działalności i badań } \\
\text { członków Zespołu Roboczego: Między par- } \\
\text { tycypacja a wykluczeniem, którego koordy- } \\
\text { natorką jest Prof. nadzw. dr hab. Małgorzata } \\
\text { Orłowska }\end{array}$ & 115 \\
\hline
\end{tabular}

Zespół Pedagogiki Chrześcijańskiej, Przewodniczący ks. prof. dr hab. Marian Nowak. Liczba osób uczestniczących w pracach Zespołu a niebędących członkami KNP PAN: 147 osób (w posiedzeniach uczestniczy zwykle ok. 1/3 zgłoszonych uczestników - średnio ok. 50 osób, w ciągu roku prawie wszyscy członkowie pojawiają się przynajmniej jeden raz!) Z członków Zespołu wskazuję na Profesorów aktualnie uczestniczących aktywnie w pracach Zespołu: Jadwiga Izdebska, Krystyna Chałas, ks. Marian Nowak, Janina Kostkiewicz, Kazimiera Krakowiak, Zenon Jasiński, O. prof. Zbigniew Marek SJ. Stopień naukowy doktora habilitowanego w zakresie pedagogiki uzyskali w ostatnich latach: Iwona Jazukiewicz (Usz), Danuta Opozda (KUL), S. Maria Loyola Opiela (KUL), S. Anna Walulik (Ignatianum), ks. S. Chrobak (UKSW), ks. Sławomir Chrost i Tadeusz Sakowicz (z UJK), Edyta Wolter (Pedagogium), Jarosław Horowski (UMK) - sekretarz Zespołu, Maria Boużyk (UKSW), Ewa Domagała- 
-Zyśk (KUL), ks. Janusz Miąso, ks. Sławomir Chrost i inni. W sumie można mówić o dość dobrej dynamice naukowych awansów członków Zespołu, jak też o dość młodym wiekowo jego składzie. Liczba odbytych posiedzeń: 4 (regularnie w każdym kwartale roku)

\begin{tabular}{|c|c|c|c|}
\hline $\begin{array}{c}\text { Miejsce } \\
\text { posiedzenia }\end{array}$ & Data & Problematyka/tematyka & $\begin{array}{c}\text { Liczba } \\
\text { uczestników }\end{array}$ \\
\hline $\begin{array}{l}\text { Instytut Pedagogiki } \\
\text { KUL, Lublin }\end{array}$ & 15 marca 2017 r. & $\begin{array}{l}\text { Przemiany spoleczno-kulturowe } \\
\text { a pedagogika katolicka }\end{array}$ & $\begin{array}{c}53 \text { osoby - człon- } \\
\text { ków Zespołu* } \\
\text { (+ ok. } 50 \text { studen- } \\
\text { tów) }\end{array}$ \\
\hline $\begin{array}{l}\text { Instytut Pedagogiki } \\
\text { KUL, Lublin }\end{array}$ & 31 maja 2017 r. & $\begin{array}{l}\text { Pedagogika katolicka dla kato- } \\
\text { lickich szkót i instytucji wycho- } \\
\text { wania chrześcijańskiego }\end{array}$ & $\begin{array}{c}47 \text { osób } \\
(+ \text { ok. } 60 \text { studen- } \\
\text { tów) }\end{array}$ \\
\hline $\begin{array}{l}\text { Kazimierz Dolny } \\
\text { n. Wisłą }\end{array}$ & $\begin{array}{l}\text { Warsztaty Metodo- } \\
\text { logiczne w dniach } \\
\text { 15-17 września (pią- } \\
\text { tek-niedziela) } 2017 \mathrm{r} \text {. }\end{array}$ & $\begin{array}{l}\text { Temat warsztatów: Jak uprawiać } \\
\text { pedagogikę katolicka?? Przeszłość } \\
\text { - teraźniejszość - przyszłość. }\end{array}$ & 49 osób \\
\hline $\begin{array}{l}\text { Instytut Pedagogiki } \\
\text { KUL, Lublin }\end{array}$ & 6 grudnia 2017 roku: & $\begin{array}{l}\text { Integralne koncepcje wychowa- } \\
\text { nia i ksztatcenia }\end{array}$ & $\begin{array}{c}47 \text { osób } \\
(+ \text { ok. } 50 \text { studen- } \\
\text { tów })\end{array}$ \\
\hline
\end{tabular}

\footnotetext{
* w spotkaniach odbywających się w KUL w Lublinie uczestniczy zwykle pewna grupa zainteresowanych studentów i doktorantów KUL kierunku pedagogika i pedagogika specjalna oraz studentów teologii i filozofii w liczbie ok. 50-60 osób. Nie zamieszczamy ich na listach uczestników.
}

Zespół Pedagogiki Chrześcijańskiej od 2005 r. posiada w Instytucie Pedagogiki KUL w Lublinie strukturę w postaci Katedry Pedagogiki Chrześcijańskiej (którą kieruje prof. KUL, dr hab. Alina Rynio), także do ośrodków badań nad chrześcijańską inspiracją w zakresie myśli pedagogicznej należą: Wydział Pedagogiki Akademii Ignatianum w Krakowie wydający m.in. czasopismo „Horyzonty Wiary", Instytut Pedagogiki a obecnie Wydział Pedagogiki i Psychologii UKSW w Warszawie wydajacy czasopismo „Forum Pedagogiczne”, poza tym pedagogika chrześcijańska uprawiana jest również na CHAT w Warszawie oraz na Wydziale Nauk Pedagogicznych UMK w Toruniu. W Toruniu na UMK z inicjatywy i pod wieloletnim kierownictwem ks. prof. dr. hab. Jerzego Bagrowicza powstało czasopismo „Paedagogia Christiana”, które jako czasopismo osiągnęło dotychczas najwyższą punktację z wyżej wymienionych czasopism i ośrodków. Paedagogia Christiana i Horyzonty Wiary posiadają patronat KNP PAN.

Zespół Teorii Wychowania. Przewodniczący - dr hab. Mirosław Kowalski, prof. UZ ; Liczba osób uczestniczących w pracach Zespołu a niebędących członkami KNP PAN - 35; liczba odbytych posiedzeń 2. Wszystkie posiedzenia miały charakter naukowy. 


\begin{tabular}{|c|c|c|c|}
\hline $\begin{array}{c}\text { Miejsce } \\
\text { posiedzenia }\end{array}$ & Data & $\begin{array}{c}\text { Liczba } \\
\text { uczestników }\end{array}$ & Problematyka/tematyka \\
\hline $\begin{array}{l}\text { Łódź, } \\
\text { Uniwersytet } \\
\text { Łódzki }\end{array}$ & 7 czerwca 2017 & 40 & $\begin{array}{l}\text { Część naukowa - seminarium naukowe } \\
\text { Kształcenie jako kategoria metahumanistyczna. } \\
\text { Źródta-modele-konteksty } \\
\text { Wystąpienia panelowe: } \\
\text { - dr hab. Krzysztof Maliszewski; } \\
\text { - dr hab. Dariusz Stępkowski prof. UKSW; } \\
\text { - prof. zw. dr hab. Bogusław Śliwerski. } \\
\text { Relacja teoria-ideologia i jej pedagogiczneledu- } \\
\text { kacyjne implikacje } \\
\text { Prezentacja pracy Ideologia, teoria, edukacja. } \\
\text { Myśl Ericha Fromma jako inspiracja dla peda- } \\
\text { gogiki wspótczesnej-dr Rafał Włodarczyk }\end{array}$ \\
\hline $\begin{array}{l}\text { Warszawa, } \\
\text { UKSW }\end{array}$ & 25 października 2017 & 28 & $\begin{array}{l}\text { Część naukowa - seminarium naukowe } \\
\text { Wychowanie moralne. Między tradycja a wspót- } \\
\text { czesnościq } \\
\text { Wystąpienia panelowe: } \\
\text { - dr hab. Jarosław Horowski (UMK w Toruniu); } \\
\text { - dr hab. prof. UO Arkadiusz Żukiewicz (Uni- } \\
\text { wersytet Opolski); } \\
\text { - ks. dr Marek Jezierski (KUL - Lublin). } \\
\text { Debata: Wychowanie moralne. Między wolno- } \\
\text { ścia i zniewoleniem. } \\
\text { Moderatorzy: dr hab. prof. UZ Mirosław Kowal- } \\
\text { ski (Uniwersytet Zielonogórski); } \\
\text { dr hab. Rafał Włodarczyk (Uniwersytet Wro- } \\
\text { cławski). } \\
\text { Sprawy różne / wolne wnioski / prezentacja pro- } \\
\text { jektowanych konferencji }\end{array}$ \\
\hline
\end{tabular}

Zespół Edukacji Elementarnej. Przewodnicząca dr hab. prof. APS Józefa Bałachowicz, liczba osób uczestniczących w pracach Zespołu a niebędących członkami KNP PAN: 60; liczba odbytych posiedzeń 4

\begin{tabular}{|c|c|c|}
\hline $\begin{array}{l}\text { Miejsce i data } \\
\text { posiedzenia }\end{array}$ & Problematyka/tematyka & $\begin{array}{c}\text { Liczba } \\
\text { uczestników }\end{array}$ \\
\hline $\begin{array}{l}\text { Akademia Peda- } \\
\text { gogiki Specjalnej } \\
\text { im. M. Grzego- } \\
\text { rzewskiej w War- } \\
\text { szawie } \\
6 \text { marca } 2017 \\
\text { roku }\end{array}$ & $\begin{array}{l}\text { Prezentacja wyników badań zespołu problemowego ZEE: Kre- } \\
\text { atywność 5-latka a poziom rozpoznania kreatywności dzieci przez } \\
\text { nauczycieli; } \\
\text { Dyskusja nad przygotowaniem nauczycieli wczesnej edukacji } \\
\text { w kontekście publikacji dr. E. Marek Przygotowanie do zawodu } \\
\text { nauczycieli edukacji wczesnoszkolnej w Polsce; } \\
\text { Zmiany programowe edukacji dziecka - analizy, opinie - stanowi- } \\
\text { ska ZEE w sprawie Podstawy programowej wychowania przed- } \\
\text { szkolnego oraz edukacji wczesnoszkolnej i Rozporządzenie MEN } \\
\text { w sprawie dopuszczenia do użytku szkolnego podręczników (pro- } \\
\text { jekt rozporządzenia z dnia } 10 \text { stycznia } 2017 \text { roku). }\end{array}$ & 32 osoby \\
\hline
\end{tabular}




\begin{tabular}{|c|c|c|}
\hline $\begin{array}{l}\text { Wydział Nauk } \\
\text { o Wychowaniu } \\
\text { Uniwersytetu } \\
\text { Łódzkiego } \\
\text { 15-16 maja } 2017 \\
\text { roku }\end{array}$ & $\begin{array}{l}\text { Tematyka konferencji „Dziecko i wczesna edukacja. Horyzonty } \\
\text { konstruktywistyczne i kognitywistyczne”. Konferencja organizo- } \\
\text { wana przez pracowników Zakład Badań Nad Dzieciństwem. } \\
\text { Konferencja została uznana przez Członkinie ZEE za okazję do } \\
\text { szerszej wspólnej dyskusji nad współczesnymi trendami i para- } \\
\text { dygmatami badań nad uczeniem się dzieci. }\end{array}$ & \\
\hline $\begin{array}{l}\text { Akademia Peda- } \\
\text { gogiki Specjalnej } \\
\text { im. M. Grzego- } \\
\text { rzewskiej w War- } \\
\text { szawie } \\
26 \text { czerwca } 2017 \\
\text { roku }\end{array}$ & $\begin{array}{l}\text { Kształcenie nauczycieli dziecka w kontekście zmian w systemie } \\
\text { szkolnictwa: } \\
\text { Współczesne trendy w przygotowaniu do zawodu nauczyciela } \\
\text { wczesnej edukacji - prezentacja wybranej problematyki publikacji } \\
\text { przygotowanej przez członków Zespołu pt. International trends in } \\
\text { preparation of early childhood teachers in a changing world, red. } \\
\text { J. Bałachowicz, K. Nowak-Fabrykowski, Z. Zbróg. } \\
\text { Społeczne reprezentacje kreatywności i kreatywnego nauczycie- } \\
\text { la podzielane przez studentów pedagogiki wczesnoszkolnej - dr } \\
\text { Marta Krasuska-Betiuk, dr Zuzanna Zbróg; osiągnięcia i braki } \\
\text { w kształceniu przyszłych nauczycieli na podstawie badań ZEE. } \\
\text { Efektem jest publikacja pt. Kreatywność jako wymiar profesjona- } \\
\text { lizacji przyszłych nauczycieli wczesnej edukacji, red. J. Bałacho- } \\
\text { wicz, I. Adamek. } \\
\text { Tutoring jako czynnik zmiany kształcenia nauczycieli wczesnej } \\
\text { edukacji-dr Anna Witkowska-Tomaszewska. }\end{array}$ & 27 osób \\
\hline $\begin{array}{l}\text { Akademia Peda- } \\
\text { gogiki Specjalnej } \\
\text { im. M. Grzego- } \\
\text { rzewskiej w War- } \\
\text { szawie } \\
6 \text { listopada } 2017 \\
\text { roku }\end{array}$ & $\begin{array}{l}\text { Wiedza osobista dziecka w świadomości i działaniach edukacyj- } \\
\text { nych nauczycieli wczesnej edukacji-prezentacja koncepcji teore- } \\
\text { tycznej i wyników badań przez dr Ewę Kochanowską. } \\
\text { Pedagogika akademicka wobec projektowanych zmian w ustroju } \\
\text { szkolnictwa wyższego w Polsce - sprawozdanie z konferencji KNP } \\
\text { PAN, JM Rektorów, Dziekanów wydziałów pedagogicznych i Dy- } \\
\text { rektorów instytutów, Białystok 23-24.10.2017 roku. } \\
\text { Planowane zmiany w kształceniu nauczycieli wczesnej eduka- } \\
\text { cji - sformułowanie Uwagi Zespołu Edukacji Elementarnej do } \\
\text { wstępnych założeń Kształcenia Nauczycieli Przedszkoli i Edukacji } \\
\text { Wczesnoszkolnej przedstawionych przez prof. dr hab. Bożenę Mu- } \\
\text { chacką w czasie posiedzenia KNP w Białymstoku }\end{array}$ & 33 osoby \\
\hline
\end{tabular}

Zespół Pedagogiki Pracy. Przewodniczący: prof. dr hab. Stefan M. Kwiatkowski. Liczba osób uczestniczących w pracach Zespołu a niebędących członkami KNP PAN: - 40, liczba odbytych posiedzeń: $\mathbf{4}$

\begin{tabular}{|l|c|l|c|}
\hline \multicolumn{1}{|c|}{$\begin{array}{c}\text { Miejsce } \\
\text { posiedzenia }\end{array}$} & Data & \multicolumn{1}{|c|}{ Problematyka/tematyka } & $\begin{array}{c}\text { Liczba } \\
\text { uczestników }\end{array}$ \\
\hline $\begin{array}{l}\text { Politechnika Koszalińska } \\
\text { (podczas Międzynarodowej } \\
\text { Konferencji „Interdyscypli- } \\
\text { narne aspekty funkcjonowa- } \\
\text { nia człowieka współczesnej } \\
\text { cywilizacji”) }\end{array}$ & 26.04 .2017 & $\begin{array}{l}\text { Debata - „Człowiek we współczesnej } \\
\text { cywilizacji” }\end{array}$ & 30 \\
\hline
\end{tabular}




\begin{tabular}{|c|c|c|c|}
\hline $\begin{array}{l}\text { Akademia Pedagogiki Spe- } \\
\text { cjalnej im. Marii Grzego- } \\
\text { rzewskiej w Warszawie }\end{array}$ & \begin{tabular}{|l|l}
12.06 .2017 \\
\end{tabular} & $\begin{array}{l}\text { Diagnoza kondycji pedagogiki pracy, } \\
\text { a także dyskusja na temat proponowa- } \\
\text { nych w Polsce zmian w systemie eduka- } \\
\text { cji, w tym edukacji zawodowej. }\end{array}$ & 55 \\
\hline $\begin{array}{l}\text { Uniwersytet Zielonogórski } \\
\text { (podczas IV Międzynarodo- } \\
\text { wego Kongresu Profesjolo- } \\
\text { gicznego Proferg 2017) }\end{array}$ & 20.06 .2017 & $\begin{array}{l}\text { Powołanie komisji do spraw właściwego } \\
\text { usytuowania zagadnień pedagogiki pra- } \\
\text { cy w treściach przedmiotów pedagogicz- } \\
\text { nych oraz rozpatrzenia celowości i moż- } \\
\text { liwości utworzenia kierunku pedagogika } \\
\text { pracy na studiach pedagogicznych; pod- } \\
\text { jęcie prac (analiza zagadnień formalno - } \\
\text { prawnych i finansowych) nad wydaniem } \\
\text { Encyklopedii Pedagogiki Pracy; } \\
\text { gala wręczenia nagród i wyróżnień Pol- } \\
\text { skiego Towarzystwa Profesjologicznego }\end{array}$ & 50 \\
\hline $\begin{array}{l}\text { Uniwersytet Kazimierza } \\
\text { Wielkiego w Bydgoszczy } \\
\text { (podczas VII Naukowego } \\
\text { Forum } \\
\text { Polsko-Ukraińskiego/Ukra- } \\
\text { ińsko-Polskiego) }\end{array}$ & 20.09.2017 & $\begin{array}{l}\text { Bieżące przekazywanie informacji o do- } \\
\text { robku poszczególnych ośrodków akade- } \\
\text { mickich i instytutów badawczych w za- } \\
\text { kresie pedagogiki pracy (publikacje, pro- } \\
\text { jekty badawcze, awanse naukowe, nowe } \\
\text { rozwiązania programowe i organizacyjne }\end{array}$ & 45 \\
\hline
\end{tabular}

Zespół Pedagogiki Społecznej wraz ze Stowarzyszeniem Pedagogów Społecznie Zaangażowanych, Przewodnicząca prof. dr hab. Barbara Smolińska-Theiss, Przewodniczący Stowarzyszenia - prof. dr hab. Tadeusz Pilch - członek KNP PAN. Liczba osób uczestniczących w pracach Zespołu a niebędących członkami KNP PAN: aktualnie w dokumentacji Zespołu - 121 członków, którzy w 2016 roku złożyli deklaracje uczestnictwa, 260 osób odwiedza stronę internetową Zespołu Pedagogiki Społecznej. Liczba odbytych posiedzeń Zespołu i Prezydium Zespołu. Cykliczne ogólnopolskie seminaria podoktorskie organizowane przez Katedry lub Zakłady Pedagogiki Społecznej w różnych uczelniach.

\begin{tabular}{|l|l|l|l|}
\hline \multicolumn{1}{|c|}{$\begin{array}{c}\text { Miejsce } \\
\text { posiedzenia }\end{array}$} & \multicolumn{1}{|c|}{ Data } & \multicolumn{1}{|c|}{ Problematyka/tematyka } & \multicolumn{1}{c|}{$\begin{array}{c}\text { Liczba } \\
\text { uczestników }\end{array}$} \\
\hline $\begin{array}{l}\text { Akademia Pedagogiki Specjalnej } \\
\text { Warszawa }\end{array}$ & $\begin{array}{l}5 \text { grudnia } \\
2016 \mathrm{r} .\end{array}$ & $\begin{array}{l}\text { Ogólnopolskie seminarium } \\
\text { podoktorskie }\end{array}$ & 51 \\
\hline $\begin{array}{l}\text { Katedra Pedagogiki Społecznej } \\
\text { Uniwersytetu Gdańskiego }\end{array}$ & 6 marca 2017 & $\begin{array}{l}\text { Ogólnopolskie seminarium } \\
\text { podoktorskie }\end{array}$ & Ponad 70 osób \\
\hline $\begin{array}{l}\text { Katedra Pedagogiki Społecznej } \\
\text { Uniwersytetu JK w Kielcach }\end{array}$ & $\begin{array}{l}26 \text { czerwca } \\
2017\end{array}$ & $\begin{array}{l}\text { Ogólnopolskie seminarium } \\
\text { podoktorskie }\end{array}$ & 86 osób \\
\hline $\begin{array}{l}\text { Zakład Pedagogiki Społecznej } \\
\text { UB w Białymstoku }\end{array}$ & $\begin{array}{l}27 \text { października } \\
2017\end{array}$ & $\begin{array}{l}\text { Ogólnopolskie seminarium } \\
\text { podoktorskie +konferencja } \\
\text { korczakowska }\end{array}$ & $\begin{array}{l}36 \text { osób semina- } \\
\text { rium, konferen- } \\
\text { cja około 200 }\end{array}$ \\
\hline $\begin{array}{l}\text { Zakład Pedagogiki Społecznej } \\
\text { UAM w Poznaniu }\end{array}$ & 8 stycznia 2018 & $\begin{array}{l}\text { Ogólnopolskie seminarium } \\
\text { podoktorskie }\end{array}$ & \\
\hline
\end{tabular}


IV.1. Konferencje naukowe zorganizowane/ współorganizowane przez Komitet lub organizowane pod patronatem Komitetu:

\begin{tabular}{|c|c|c|c|c|c|c|c|}
\hline $\begin{array}{c}\text { Nazwa } \\
\text { konferencji }\end{array}$ & Organizator & $\begin{array}{r}\text { Roc } \\
\text { konfe }\end{array}$ & encji & $\begin{array}{r}\text { Lic } \\
\text { uczes }\end{array}$ & $\begin{array}{l}\text { zba } \\
\text { ników }\end{array}$ & Liczba & Dofinans. \\
\hline data, miejsce & $\begin{array}{l}\text { współorgani- } \\
\text { zatorzy }\end{array}$ & krajowa & $\begin{array}{c}\text { mię- } \\
\text { dzyna- } \\
\text { rodowa }\end{array}$ & ogółem & $\begin{array}{l}\text { z za- } \\
\text { granicy }\end{array}$ & wystąpień & $\begin{array}{l}\text { ze środków } \\
\text { DUN (w zł) }\end{array}$ \\
\hline $\begin{array}{l}\text { XXXI Letnia } \\
\text { Szkoła Mło- } \\
\text { dych Peda- } \\
\text { gogów KNP } \\
\text { PAN } \\
\text { Warszawa, } \\
\text { 11-16 września } \\
2017 \text { r. }\end{array}$ & $\begin{array}{l}\text { Wydział } \\
\text { Nauk Peda- } \\
\text { gogicznych } \\
\text { UKSW } \\
\text { w Warszawie }\end{array}$ & $\mathrm{X}$ & & 55 & & 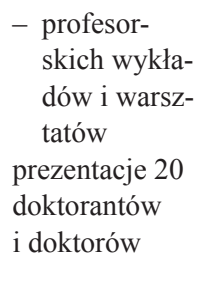 & $\begin{array}{l}20000 \text {,-zł } \\
\text { (koszt całko- } \\
\text { wity: } \\
\mathbf{7 4 ~ 4 8 0 , 5 2 )}\end{array}$ \\
\hline
\end{tabular}

\section{Letnia Szkoła Młodych Pedagogów Komitetu Nauk Pedagogicznych PAN}

nosząca tytuł Problemy z własnym lub cudzym warsztatem pisarstwa naukowego odbyła się w dniach 11-16 września 2017 roku w Katolickim Centrum Kultury Dobre Miejsce w Warszawie, ul. Dewajtis 3. Gospodarzem XXXI LSMP był Wydział Nauk Pedagogicznych Uniwersytetu Kardynała Stefana Wyszyńskiego. W tym naukowym wydarzeniu udział wzięło 39 młodych uczestników - pedagogów z całego kraju, sześcioosobowy Komitet Organizacyjny Wydziału Nauk Pedagogicznych UKSW, 11 zaproszonych gości - Profesorów z różnych dziedzin nauki. Opiekę merytoryczną nad Szkołą sprawowali: prof. Maria Dudzikowa Kierownik Naukowy Szkoły (prowadząca szkołę po raz dwudziesty czwarty) oraz Przewodniczący Komitetu Nauk Pedagogicznych PAN prof. Bogusław Śliwerski.

Doktoranci i młodzi doktorzy mieli możliwość wysłuchania wykładów Mistrzów polskiej humanistyki i nauk społecznych:

prof. Tadeusz Sławek - z Uniwersytetu Śląskiego: Edukacja jako tworzenie i podtrzymywanie kultury nadziei

prof. Bogusław Śliwerski (UŁ) - Pisanie recenzji dorobku na awans zawodowy

dr hab. Marek Wroński (PWSZ w Kaliszu) - Nierzetelność naukowa w publikacjach akademickich.

dr hab. Marek Furmanek (UZ) - Język prezentacji medialnej-językiem komunikacji z odbiorca. 
dr hab. Maria Boużyk (WNP UKSW) - Każdy jest filozofem? O roli edukacji filozoficznej w ksztatceniu pedagogów.

prof. Mariusz Zemło - Językowe uwarunkowania wiedzy

prof. Stanisław Gajda - Komunikacja w nauce w perspektywie lingwistycznej.

prof. Jolanta Maćkiewicz z Uniwersytetu Gdańskiego - Jak pisać prace naukowe.

prof. Andrzej Góralski z APS - Jak pisać wiersze

dr hab. Witold Starnawski - Twórczość Jana Pawła II. Zbyt łatwa, czy za trudna, czyli o lekturze znanego w świecie, nieczytanego w kraju Autora.

prof. Krzysztof Rubacha (UMK) - Analiza jakościowa wyników badań empirycznych.

Efekty LSMP:

Przygotowanie sprawozdania i publikacja na stronie internetowej http://smp. pedaogigka.uksw.edu.pl

Publikacja sprawozdania w półroczniku „Forum Młodych Pedagogów” przy Komitecie Nauk Pedagogicznych PAN

Publikacja sprawozdania w „Forum Pedagogicznym” - wydawanym przez Wydział Nauk Pedagogicznych UKSW

Publikacja wystąpień uczestników Zeszytach Młodych - publikacji pokonferencyjnej wydawanej przez Wydział Nauk Pedagogicznych UKSW

Publikacja nagrodzonych podczas XXXI Letniej Szkoły Młodych Pedagogów wystąpień w „Roczniku Pedagogicznym” wydawanym przy Komitecie Nauk Pedagogicznych PAN

Udostępnianie informacji na temat wyników XXXI LSMP i publikacji poprzez „Międzyszkolnik” - internetowy newsletter rozsyłany do całej wspólnoty uczestników Letnich Szkół.

Prezentowanie w czasie śródrocznych posiedzeń zespołów zadaniowych przy KNP PAN dalszych postępów w pracy naukowej nad doktoratem czy habilitacją.

IV.2. Omówienie wyników konferencji patronackich z punktu widzenia znaczenia dla reprezentowanej przez Komitet dyscypliny naukowej.

Efektem konferencji jest upowszechnianie wyników badań naukowych, utrzymywanie koniecznej więzi nauki z praktyką - z środowiskiem oświatowym i pozaszkolnych, a działającym na rzecz wychowania, resocjalizacji czy diagnostyki edukacyjnej. Zostało to odnotowane w powyższych a syntetycznych danych o pracy poszczególnych zespołów zadaniowych. W wyniku tak szerokiej aktywności ukazało się kilkadziesiąt rozpraw naukowych, monografii zbiorowych i autorskich, zaś wśród tych ostatnich znajdują się publikacje będące podstawą do ubiegania się o awans naukowy. W wyniku prowadzonej od ponad sześciu lat 
nowej polityki KNP PAN nastąpiła wyraźna aktywizacja środowisk akademickich w naszej dyscyplinie w zakresie $\mathrm{z}$ jednej strony eliminowania patologii, a $\mathrm{z}$ drugiej - podnoszenia na coraz wyższy poziom własnych projektów badawczych i wydawanych publikacji. Do konferencji cyklicznych należy zaliczyć cykl ogólnopolskich i międzynarodowych konferencji naukowych: z okazji Międzynarodowego Dnia Rodziny odbywających się rokrocznie w Kielcach - 15 maja i związanych z realizacją zaleceń Zgromadzenia Ogólnego Narodów Zjednoczonych i Kościoła katolickiego, zainicjowanych w 1994 roku i odnoszących się do systematycznego podnoszenia świadomości społeczeństwa w zakresie problematyki rodzinnej oraz skuteczniejszej i kompleksowej polityki państwa w tym zakresie. Świętokrzyskie Obchody Międzynarodowego Dnia Rodziny zaznaczyły się jako jedyne, co do systematyczności i wytrwałości w służbie rodzinie i społeczeństwu. Zespół Pedagogiki Chrześcijańskiej włączył się w tę inicjatywę, zwłaszcza od roku 2006, dołączając do Instytutu Pedagogiki i Psychologii przy Wydziale Pedagogicznym i Artystycznym UJK wraz z Świętokrzyskim Urzędem Wojewódzkim, Prezydentem Miasta Kielce, Urzędem Marszałkowskim Województwa Świętokrzyskiego, diecezją kielecką oraz organizacjami pozarządowymi Kielc i województwa świętokrzyskiego - jako podmiotami tej konferencji. Idea jednoczenia wszystkich sił społecznych dla działań zmierzających do rozpoznawania i rozwiązywania problemów, które nie tylko nękają współczesną rodzinę polską, czy szkołę, ale również ukazują jej doniosłość, piękno i wartość, zarówno w indywidualnym, jak też globalnym wymiarze. Komitet Organizacyjny tych konferencji tworzą pracownicy Zakładu Profilaktyki Społecznej i Resocjalizacji Instytutu Pedagogiki i Psychologii przy Wydziale Pedagogicznym i Artystycznym UJK, natomiast w skład Komitetu Naukowego wchodzą najczęściej uczestniczący w Konferencji profesorowie z ośrodków naukowych z całego kraju. Funkcję przewodniczącego wszystkich Komitetów pełni pomysłodawca przedsięwzięcia, ks. prof. zw. dr hab. Jan Śledzianowski, wieloletni Kierownik Zakładu Profilaktyki Społecznej i Resocjalizacji, który po przejściu na emeryturę w 2009 roku, nadal pełni tę funkcję honorowo. Każdego roku ukazuje się publikacja stanowiąca pokłosie takich obchodów.

Niezwykle istotne jest utrzymywanie stałej, cyklicznej współpracy z dziekanami wszystkich wydziałów uniwersyteckich i akademii pedagogicznych, w których prowadzone są badania naukowe z pedagogiki i ma miejsce kształcenie pedagogiczne. Członkowie KNP PAN znakomicie współpracują z środowiskowymi władzami samorządowymi w dziedzinie oświaty, pomocy społecznej i resocjalizacji. Zwiększa to szacunek dla nauki i sprzyja wysokiemu prestiżowi PAN.

Patronatem obejmowano tylko konferencje cykliczne, poświęcone kluczowym zagadnieniom pedagogiki i jej subdyscyplin oraz metodologii badań. Komitet Nauk Pedagogicznych przyjął kryteria, zgodnie z którymi udziela patronatu 
tylko nielicznym konferencjom - najczęściej międzynarodowym i ogólnokrajowym, ale bardzo dobrze udokumentowanym w swoich założeniach programowych, posiadających w komitecie programowym co najmniej dwóch członków KNP PAN. W materiałach konferencyjnych/pokonferencyjnych jest publikowana informacja o Komitecie Nauk Pedagogicznych PAN oraz wydawanych przez komitet czasopismach naukowych, zaś Organizator informuje o tym, kto imiennie przygotuje sprawozdanie z konferencji i przesyła je w ciągu miesiąca po jej zakończeniu. Najważniejszym efektem jest jednak rozpoznanie przy tej okazji naukowców o najwyższym potencjale eksperckim, do których można zwracać się po opinie np. projektów rozporządzeń MEN i MNiSW.

\section{INNE FORMY DZIAŁALNOŚCI UPOWSZECHNIAJĄCEJ I PROMUJĄCEJ NAUKĘ}

(audycje i programy w radiu i telewizji, udział w festiwalach nauki, piknikach naukowych, wystąpienia w mediach elektronicznych, artykuły w prasie popularyzujące naukę itp. - dotyczy działań, w których bezpośrednio zaangażowany był Komitet lub jego struktury wewnętrzne).

Członkowie Komitetu Nauk Pedagogicznych byli bardzo aktywni w debatach publicznych na temat projektowanych i wdrażanych reform w obszarze oświaty oraz szkolnictwa wyższego i nauki, publikując artykuły w prasie ogólnopolskiej, udzielając mediom wywiadów, komentarzy oraz publikując stałe felietony. Były to m.in.:

1) Śliwerski B., Siłą polskiej edukacji są nauczyciele, http://www.radio.rzeszow.pl/wiadomosci/1485/prof-b-sliwerski-sila-polskiej-edukacji-sa-nauczyciele

2) Śliwerski B., Eksperci alarmuja: MEN udaje, że zmienia podstawy programowe, wywiad prowadzila Anna Wittenberg 2.02.2017 „Dziennik. Gazeta Prawna”.

3) Śliwerski B. Opinia - Wójcik K., Prawo o szkolnictwie wyższym nowe typy uczelni, 18.01.2017 „Dziennik. Gazeta Prawna”. HTTP:// WWW.RP.PL/EDUKACJA-I-WYCHOWANIE/301189925-PRAWO-O-SZKOLNICTWIE-WYZSZYM---NOWE-TYPY-UCZELNI.HTML\#AP-2.

4) Pedagodzy miażḋa projekt podstawy, „Głos Nauczycielski” 15.01 .2017 http://www. glos.pl/node/17844.

5) Dorota Gołębniak - Organizowanie otwartego cyklu środowiskowych seminariów i warsztatów metodologicznych pod hasłem „Spotkania naukowe w Rotundzie" (Collegium da Vinci w Poznaniu), we współpracy z uczelniami: Uniwersytetem Adama Mickiewicza w Poznaniu, Uniwersytetem Ekonomicznym w Poznaniu, Uniwersytetem Kazimierza Wielkiego 
w Bydgoszczy, Uniwersytetem Warmińsko-Mazurskim w Olsztynie oraz Dolnośląską Szkołą Wyższą we Wrocławiu.

6) D. Klus-Stańska (2017), Uwagi do podstawy programowej kształcenia ogólnego. „Forum Oświatowe” t. 29, nr 1 (57), s. 249-255.

7) Wywiad z D. Klus-Stańską (rozmawia Ewa Furche) (2016, 2017), Zadania wspótczesnej szkoły a polska rzeczywistość oświatowa. Cz. I i II. „Edukacja Pomorska" nr 77/78 (28/29), s. 47-51.

8) D. Klus-Stańska, Centrum Inicjatyw Edukacyjnych w Kartuzach, 9. 06. 2017 Kartuzy, Seminarium nt. „Jak rozmawiać o wartościach?”, wystąpienie: Jak rozmawiać z dziećmi i młodzieżą o wartościach?

9) D. Klus-Stańska, Centrum Edukacji i Inicjatyw Kulturalnych w Olsztynie, seminarium Festiwal Edukacji Kulturowej w programie „Wędrowna Akademia Kultury", finansowanym przez Narodowe Centrum Kultury, 6. 11. 2017 r. Olsztyn, wykład: Młodzi i edukacja kulturowa.

10) M. Groenwald, Centrum Edukacji Nauczycieli w Gdańsku, Goethe Institut w Warszawie, Uniwersytet Gdański; Międzynarodowa Konferencja „Szkoła empatii, dialogu i inspiracji”, Gdańsk 25.09,2017. Wypowiedź ekspercka: „Jak przygotować do pracy z uczniami nauczycieli świadomych potrafiących działać na rzecz dobra ogólnego ludzi”;

11) Dariusz Chętkowski, Szkoły będa uczyć postuszeństwa http://chetkowski.blog.polityka.pl/2017/01/16/szkoly-beda-uczyc-posluszenstwa/\#more-8361

12) Rzad kształtuje „nowego Polaka”. MEN chce uczyć dzieci w szkołach postuszeństwa, a nie samodzielnego myślenia, [w:] http://natemat.pl/199495,ksztaltowanie-nowego-polaka-postepuje-men-chce-by-zamiast-samodzielnego-myslenia-uczono-w-szkolach-posluszenstwa

13) Nauczyciel transformatywny. Wywiad z prof. Marią Czerepaniak-Walczak, „Głos Nauczycielski” 2017 nr 12.

14) E. Filipiak, Uniwersytet Kazimierza Wielkiego w Bydgoszczy, Departament Edukacji i Kształcenia Ustawicznego Urzędu Marszałkowskiego Województwa Kujawsko-Pomorskiego, Kujawsko-Pomorskie Centrum Edukacji Nauczycieli w Bydgoszczy, Kujawsko Pomorskie Centrum Edukacji Nauczycieli w Toruniu i Kujawsko Pomorskie Centrum Edukacji Nauczycieli we Włocławku; Konferencja: „Budowanie jakości sieci współpracy i samokształcenia - w kierunku rozwoju kultury szkoły i jej uczestników"; referat: Sieci wspótpracy i samoksztatcenia - w kierunku rozwoju kultury szkoły i jej uczestników.

15) Udział w Festiwalu Nauki organizowanym na uczelniach - w tej formie popularyzacji nauki uczestniczy większość członków Zespołu (UMK. UW, KUL). 
16) Członkowie prowadzą wykłady i organizują konferencje popularyzujące naukę. Dla przykładu: dr hab. P. Gołdyn, prof. UAM - Wykład na temat: Ideaty wychowania $w$ II Rzeczypospolitej w ramach sesji popularnonaukowej - IX dekad konińskiej „,Jedynki” w historii naszego miasta - Konin, 30 marca 2017 r.; wykład dla studentów historii Wschodnioeuropejskiego Narodowego Uniwersytetu im. Łesi Ukrainki - Walka z handlem kobietami i dziećmi w II RP - Łuck, 19 maja 2017 r.; wykład w ramach konferencji czytelniczej Książi, które czytają Ciebie i ttumacza świat, na temat: Jak czytać, jak pisać kronike szkolną? - Rzeszów, 6 czerwca 2017 r.; wykład w ramach projektu Od kałamarza do komputera. Historia i tradycja edukacji w kłodawskiej „,Jedynce” - Kłodawa, 9 listopada 2017 r.; wykład dla uczniów ZSP w Kleczewie - Krótkie obrazki z dziejów oświaty w Wielkopolsce Wschodniej-Kleczew, 14 grudnia 2017 r.

17) Działalność promująca region w grupie inicjatywnej Korowodu Kociewskiego (w ramach obchodów Dni Kociewia w Gdańsku - 3.08.2017), wraz z Powiatem Świeckim oraz Izbą Regionalną Ziemi Świeckiej (dr J. Stelągowska-Cukras z UMK).

18) Wykłady: Bogu, Ojczyźnie, Przyjaźni. Zakład naukowo-wychowawczy $w$ Chyrowie jezuickim wzorem edukacji w ramach Uniwersytetu Drugiego i Trzeciego Wieku przy parafii św. Ducha w Nowym Sączu, 12 XII 2017. (o dr. A. Bieś, Ignatianum).

19) VI Konferencja Dzieci i Młodzieży zorganizowana w ramach Tygodnia Dziecka w Białymstoku (8-15 października 2017), miejsce: Wydział Pedagogiki i Psychologii Uniwersytet w Białymstoku, 13 października 2017 (dr A. Suplicka).

20) Humanistyka na przyszłość - przygotowanie tekstów prasowych promujących pedagogikę jako dyscyplinę (dr A. Królikowska, Ignatianum);

21) Organizacja spotkań otwartych z cyklu: „Dzieje pedagogiki toruńskiej” na Wydziale Nauk Pedagogicznych UMK w Toruniu, których celem jest prezentacja historii powstania i dorobku naukowego pracowników związanych z pedagogiką toruńską (dr Joanna Falkowska, dr Dorota Grabowska-Pieńkosz).

22) Audiobook przygotowany z okazji jubileuszu 70-lecia Zespołu Szkół Przemysłu Spożywczego i 25-lecia VIII Liceum Ogólnokształcącego w Toruniu. Podstawą do zrealizowania tego projektu była praca dyplomowa pt. Zespół Szkół Przemystu Spożywczego w Toruniu. Działalność wychowawcza w latach 1947-1991, która powstała w Katedrze Historii Myśli Pedagogicznej pod kierunkiem dr Joanny Falkowskiej.

23) Współtworzenie i współprowadzenie wraz z fundacją Art., od września 2016 do czerwca 2017, projektu edukacyjnego dla młodzieży gimna- 
zjalnej i licealnej - „Dialogi o Niepodległej”, zamówionego przez Biuro Edukacji Miasta Warszawy (dr K. Buczek)

24) Autorstwo teatralnego scenariusza „Poplątałeś Wisłę” w ramach cyklu „Królewskie spacery” realizowanego w wakacje 2017 na Zamku Królewskim w Warszawie. (dr K. Buczek)

25) Tworzenie scenariusza i pisanie opowiadania oraz współprowadzenie comiesięcznych zajęć w ramach cyklu „Szkatułka królewny, Skarb królewicza" dla dzieci w wieku 3-6 lat realizowanych w Zamku Królewskim w Warszawie (dr K. Buczek).

26) Organizacja cyklicznych konferencji i warsztatów - w roku 2017 VI Dębickiej Debaty o Wychowaniu: 21 kwietnia 2017 roku w ramach „VI Dębickiej Debaty o Wychowaniu" odbyły się warsztaty dla uczniów szkół gimnazjalnych i ponadgimnazjalnych oraz konferencja naukowa pod hasłem: „Czas rodzinny. Dar i zadanie” (s. dr hab. prof. KUL Maria Opiela).

27) Promocja książki D. Żołądź-Strzelczyk, I. Gomułki, K. Katarzyny Kabacińskiej - Łuczak Dzieje zabawek dziecięcych na ziemiach polskich do poczatku XX wieku 24.10.2017 w Muzeum Zabawek w Kudowie-Zdroju; promocja książki Zabawka - przedmiot ludyczny i obiekt kolekcjonerski pod red. nauk. dr Katarzyny Kabacińskiej-Łuczak oraz prof. zw. dr hab. Doroty Żołądź-Strzelczyk; Wydawnictwo Naukowe UAM oraz Publiczna Biblioteka Pedagogiczna w Poznaniu, 23 lutego 2017 w Salonie Mickiewicza Collegium Maius.

28) Opublikowane teksty: Ideaty wychowawcze w okresie II Rzeczypospolitej, [w:] Szkoła Podstawowa nr 1 im. Zofii Urbanowskiej w Koninie 1927-2017, Konin 2017, s. 17-19; Znamienity przykład pracy z patronem szkoły, „Koniński Kurier Oświatowy” 2017, nr 2, s. 10-12.

29) Publikacje zawarte w czasopismach afiliowanych przez Zespół: Edukacja Międzykulturowa (na stronie: http://weinoe.us.edu.pl/nauka/nauka-weinoe/serie-wydawnicze/edukacja-miedzykulturowa), Multicultural Studies (więcej informacji na stronie: http://mcs.uni.wroc.pl/pl/mcs/).

30) Spotkanie Zespołu Pedagogiki Ogólnej KNP PAN (Warszawa, 21 kwietnia 2017 r.), autor: Krystyna Heland-Kurzak, sprawozdanie opublikowane w „Forum Pedagogicznym” 2017, nr 2

31) Jarosław Gara: Fenomenologiczna kategoria świata życia codziennego jako przesłanka eksplikacji sensów edukacji, „Forum Pedagogiczne” 2017, nr 2 (tekst stanowi zapis wystąpienia dra hab. Jarosława Gary prezentowanego na posiedzeniu ZPO KNP PAN w 2016 roku)

32) Powołanie Zespołu Roboczego do spraw informacji i promocji dorobku z obszaru pedagogiki młodzieży 
33) Członkowie Zespołu Pedagogiki Młodzieży zaznaczali swoją czynną obecność podczas następujących wydarzeń upowszechniających i promujących naukę: Festiwalu Nauki i Sztuki na UAM - 2017; VIII Festiwalu Kultury Studentów Kulminacje na WSE i WNS UAM - 2017; Festynie Rodzinnym UAM - 2017.

34) Radosław Nawrocki, Jak demon biurokracji niszczy szkołe i nauczyciela, „Nowe Horyzonty Edukacji” 2015, nr 2(12), ISSN 2084-1108, s. 48-52.

\section{DZIAŁALNOŚĆ EKSPERCKA, OPINIE, OCENY I KONSULTACJE W ROKU SPRAWOZDAWCZYM.}

VI. 1. Raport środowiska naukowego PAN dotyczący integracji europejskiej i miejsca Polski w tym procesie pod red. prof. Jerzego Wilkina, czł. rzecz. PAN. Przewodniczący KNP PAN prof. dr hab. B. Śliwerski dr h.c. multi przygotował część dotyczącą edukacji.

VI. 2. Ekspertyzy ${ }^{1}$

Komitet Nauk Pedagogicznych przygotował opinie dotyczące:

1. Ekspertyza prof. dr. hab. Tadeusza Pilcha na temat polityki oświatowej rządu PIS w środowiskach wiejskich w związku z wdrażaną od 1.09.2017 r. reformą ustrojową szkolnictwa.

2. Ekspertyzy prof. dr hab. Barbary Kromolickiej jako członka Narodowej Rady Rozwoju przy Prezydencie RP w sekcji ds. polityki społecznej i rodziny oraz w sekcji dotyczącej edukacji i szkolnictwa wyższego.

3. Ekspertyza prof. dr. hab. Bogusława Śliwerskiego na temat awansów naukowych w dyscyplinie pedagogika w świetle danych z prac członków Sekcji I Nauk Humanistycznych i Społecznych w nowej kadencji Centralnej Komisji Do Spraw Stopni i Tytułów. Opublikowanie diagnozy związanej z postępowaniami habilitacyjnymi w Sekcji I Nauk Humanistycznych i Społecznych CK w latach 2013-2016.

4. Opracowanie przez prof. dr. hab. Marka Konopczyńskiego dla MEN założeń programu wychowawczo-profilaktycznego oraz treści i zadań wychowawczo-profilaktycznych do realizacji przez nauczycieli i wychowawców szkół i placówek oświatowych obowiązujących od 1.09.2017 r.

\footnotetext{
${ }^{1}$ Jako ekspertyzy należy traktować wyłącznie opracowania analityczne przedstawiające stan problematyki stanowiącej przedmiot ekspertyzy, proponowane kierunki działań dla rozwiązania problemu, wraz z propozycjami zastosowań oraz wskazaniem adresatów i odbiorców, którzy te wnioski mogą wprowadzić i określeniem konkretnych efektów, jakie te rozwiązania mogą przynieść.
} 
1. Opinia KNP PAN dla posłów Sejmu VIII kadencji w sprawie powstrzymania przygotowywanej przez Ministerstwo Nauki i Szkolnictwa Wyższego likwidacji dotychczas obowiązującej części listy B wykazu czasopism punktowanych MNiSW.

2. Sekcja Polityki Oświatowej Komitetu Nauk Pedagogicznych PAN przedłożyła MEN uwagi ogólne i szczegółowe do przekazanych do konsultacji społecznej projektów rozporządzeń:

Opinie dla MEN

Opinia projektu rozporzadzenia Ministra Edukacji Narodowej w sprawie udzielania jednostkom samorzadu terytorialnego dotacji celowej $\mathrm{z}$ budżetu państwa na dofinansowanie zadań w zakresie wychowania przedszkolnego

UWAGI DO PROJEKTU ROZPORZĄDZENIA MINISTRA EDU KACJI NARODOWEJZMIENIAJĄCE ROZPORZĄDZENIE WSPRA WIE SPOSOBU REALIZACJI EDUKACJI DLA BEZPIECZEŃSTWA Z 31 MARCA 2017 R.

Opinia o projekcie Rozporządzenia Ministra Edukacji Narodowej w sprawie dopuszczenia do użytku szkolnego podręczników (projekt rozporządzenia z dnia 10 stycznia 2017 r.)

Opinia KNP PAN projektu „Rozporządzenie Ministra Edukacji Narodowej w sprawie ramowych planów nauczania dla publicznych szkól”

Zespół Pedagogiki Społecznej przy Komitecie Nauk Pedagogicznych przekazał opinię zawierającą najwyższy niepokój i dezaprobatę dla planów cofnięcia obowiązku szkolnego dla dzieci 6-letnich.

Uwagi Zespołu Dydaktyki i Zespołu Edukacji Elementarnej KNP PAN do Podstawy programowej ksztal cenia ogól nego dl a szkoły podstawowej

Opinia dotycząca Projektu rozporzadzenia Ministra Edukacji Narodowej w sprawie wymagań wobec szkót i placówek;

Uwagi Zespołu Edukacji Elementarnej do wstępnych założeń Kształcenia Nauczycieli na Kierunkach Pedagogicznych

\section{Opinie dla MNiSW:}

Stanowisko w sprawie powstrzymania przygotowywanej przez Ministerstwo Nauki i Szkolnictwa Wyższego likwidacji dotychczas obowiązującej części listy B wykazu czasopism punktowanych MNiSW.

Opinia Sekcji ds. Polityki Szkolnictwa Wyższego i Parametryzacji Jednostek Naukowych Komitetu Nauk Pedagogicznych PAN dotycząca projektu Ustawy 2.0. 
Opinia dla Rzecznika Praw Obywatelskich

Opinia Zespołu Pedagogiki Specjalnej, funkcjonującego przy Komitecie Nauk Pedagogicznych Polskiej Akademii Nauk dotycząca nierównego traktowania dzieci i młodzieży z niepełnosprawnością intelektualną w stopniu głębokim w polskim systemie oświaty.

\section{INNE DZIAŁANIA WYNIKAJĄCE ZE SPECYFIKI DZIAŁANIA KOMITETU}

Pod patronatem Komitetu Nauk Pedagogicznych Polskiej Akademii Nauk odbyła się w 2017 r. kolejna edycja Ogólnopolskiego Sprawdzianu Czytania ze Zrozumieniem pod hasłem: „Rozumiem to, co czytam. Czytam to, co rozumiem”. Pomysłodawcą oraz organizatorem sprawdzianu i autorem tekstów do sprawdzianu jest warszawski polonista, założyciel Centrum Edukacji Humanistycznej „LOGOS" - mgr Andrzej Michalski. Celem sprawdzianu było zdiagnozowanie poziomu umiejętności czytania ze zrozumieniem wśród dzieci i młodzieży od pierwszej klasy szkoły podstawowej do trzeciej klasy szkoły ponadgimnazjalnej oraz zwrócenie uwagi na umiejętność czytania ze zrozumieniem jako jednego z kluczowych komponentów alfabetyzacji młodych pokoleń. Organizatorzy uwzględnili w sprawdzianie, którego narzędziem był test z pytaniami zamkniętymi, następujące umiejętności: rozpoznawanie znaczenia wyrazów niezbędnych do zrozumienia tekstu; czytanie tekstów: poetyckich, literackich, publicystycznych, użytkowych; ikonograficznych, tabel i wykresów, przypisów; czytanie na poziomie dosłownym; czytanie poleceń; czytanie na poziomie przenośnym.

Udział KNP PAN w Jubileuszu Katedry Historii Wychowania WSE UAM w Poznaniu, Jubileuszu Wydziału Pedagogiki i Psychologii Uniwersytetu w Białymstoku.

\section{WRĘCZENIE WYRÓŻNIEŃ KNP PAN:}

\section{MEDAL ZA ZASŁUGI DLA ROZWOJU POLSKIEJ PEDAGOGIKI}

Kapituła Medalu Komitetu Nauk Pedagogicznych PAN „Za Zasługi Dla Rozwoju Polskiej Pedagogiki” podjęła uchwałę o przyznaniu Medalu w 2017 r. następującym Profesorom:

1. Prof. dr hab. Jerzy Niemiec

2. Prof. dr hab. Bogdan Szczepankowski

3. Prof. dr hab. Karol Poznański

4. Prof. dr hab. Alicja Kargulowa

Wyróżnieni Profesorowie zostali nominowani i zaopiniowani zgodnie z Regulaminem MEDALU. 


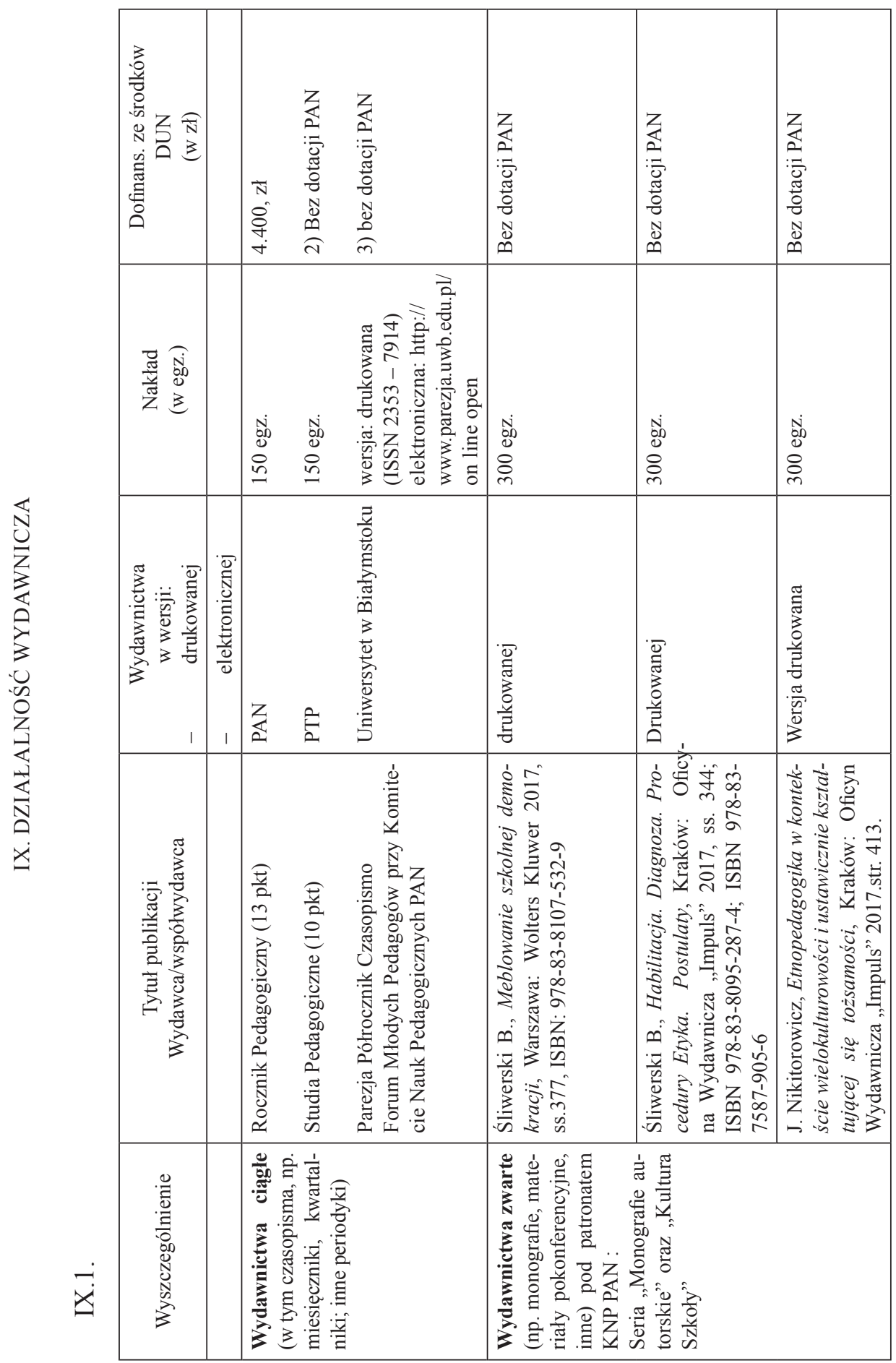




\begin{tabular}{|c|c|c|}
\hline & 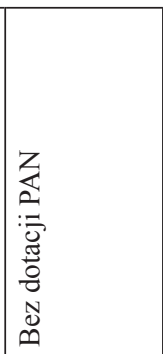 & 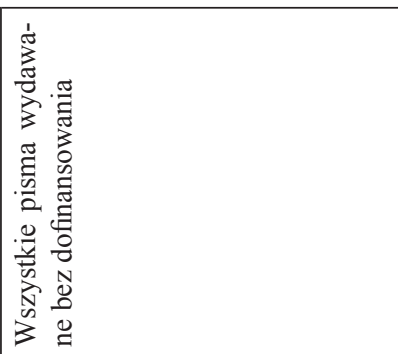 \\
\hline & 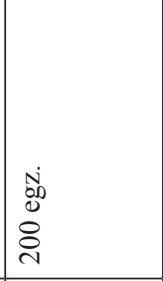 & فُ \\
\hline & 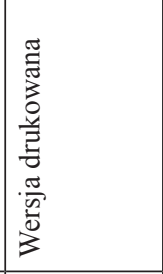 & 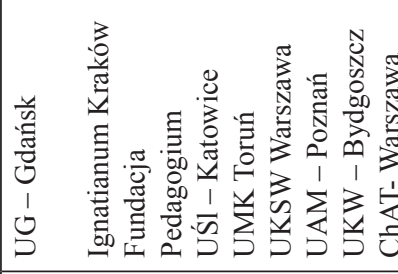 \\
\hline 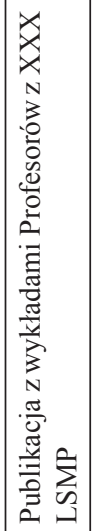 & 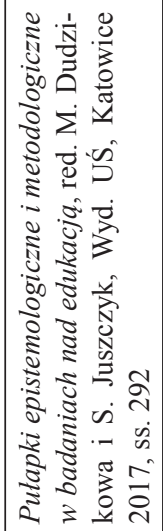 & 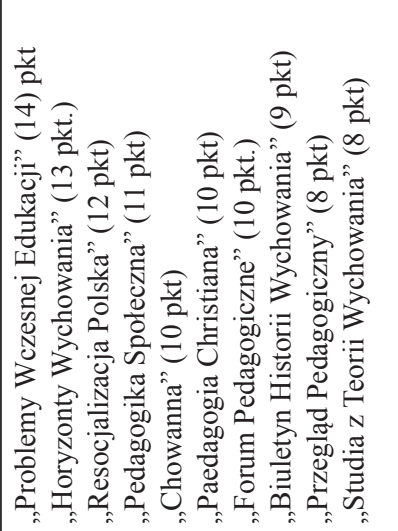 \\
\hline & & 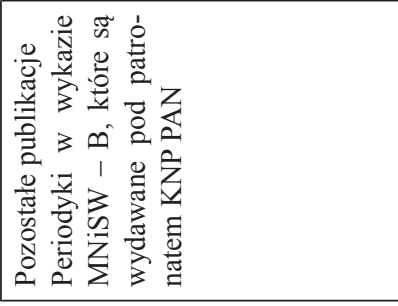 \\
\hline
\end{tabular}


IX.2. Omówienie działalności wydawniczej Komitetu w roku sprawozdawczym

Komitet Nauk Pedagogicznych kładzie szczególny akcent na podwyższenie jakości upowszechniania najlepszego dorobku naukowego oraz rozwoju kadr akademickich. Utrzymujemy stały cykl wydawniczy dwóch serii monograficznych:

a) „Monografie autorskie" pod red. Bogusława Śliwerskiego

W tym roku ukazały się dwa nowe tomy: vol. 16 (B. Śliwerski, Habilitacja. Diagnoza. Procedury Etyka. Postulaty) i vol. 17 (J. Nikitorowicz, Etnopedagogika w kontekście wielokulturowości i ustawicznie kształtującej się tożsamości). W przygotowaniu są kolejne monografie na rok 2018.

b) W ramach uruchomionej nowej serii wydawniczej we współpracy z Wydawnictwem Kluwer w Warszawie: „Kultura szkoły” pod red. Marii Dudzikowej i Ewy Bochno ukazał się II tom monografii naukowej autorstwa B. Śliwerskiego pt. Meblowanie szkolnej demokracji.

c) Monografia referatów profesorów uczestniczących w XXX Letniej Szkoły Młodych Pedagogów KNP PAN w Wiśle a sfinansowana przez Wydział Pedagogiki i Psychologii Uniwersytetu Śląskiego w Katowicach pod red. prof. dr hab. Marii Dudzikowej i prof. dr. hab. Stanisława Juszczyka pt. Pułapki epistemologiczne i metodologiczne w badaniach nad edukacja. Jak sobie z nimi radzić? (Katowice 2017, ss.292).

d) W 2017 r. zostało wydane kolejne wystandaryzowane narzędzie badawcze - Kwestionariusz Gotowości Przeciwstawiania się autorstwa Sławomira Pasikowskiego (Przeglad Badań Pedagogicznych 2017 nr 23a, ss. 44)

\section{AKTYWNOŚĆ MIĘDZYNARODOWA KOMITETU}

Współpraca Komitetu z organizacjami międzynarodowymi w zakresie reprezentowanej dyscypliny/ problemu naukowego (m.in. pełnienie przez Komitet funkcji komitetu narodowego ds. współpracy z organizacjami naukowymi, współpraca $\mathrm{z}$ innymi międzynarodowymi organizacjami naukowymi, udział członków Komitetu we władzach, pracach komisji, komitetów itp. międzynarodowych organizacji naukowych.

Bilateralna współpraca zagraniczna KNP PAN z Ukraińskim Komitetem Nauk Pedagogicznych trwa od 1995 roku. W ramach tej współpracy zorganizowano w $2017 \mathrm{r}$ :

VII Forum Naukowe „POLSKA-UKRAINA” (na Uniwersytecie Kazimierza Wielkiego w Bydgoszczy w dniach 19-21.09.2017 r.)

Wydano kolejny tom: Edukacja Zawodowa i Ustawiczna. Polsko-Ukraiński Rocznik Naukowy 2017 Nr 2 (ISSN 2543-7925) 
Podczas VII Forum w Kijowie złożono kwiaty i oddano hołd poległym na Majdanie.

Współpracę prowadzi Zespół Pedagogiki Pracy przy Komitecie Nauk Pedagogicznych PAN od ponad dwudziestu lat, którego uczeni ściśle współpracują z uczonymi na Ukrainie. Są tu naukowcy m.in. z Akademii Pedagogiki Specjalnej im. Marii Grzegorzewskiej w Warszawie, Uniwersytetu Marii Curie Skłodowskiej w Lublinie, Uniwersytetu Kazimierza Wielkiego w Bydgoszczy, Uniwersytetu Techniczno-Humanistycznego w Radomiu czy Akademii im. Jana Długosza w Częstochowie. Nadzwyczajny i Pełnomocny Ambasador Ukrainy -Andrij Deszczyc i Prezydenta Narodowej Akademii Pedagogicznych Nauk Ukrainy prof. dr. hab. Wasil Kremień przekazali w dn. 18.09.2017 r. w Ambasadzie Ukrainy w Warszawie dyplomy uznania prof. dr. hab. Stefanowi M. Kwiatkowskiemu i prof. dr. hab. Franciszkowi Szloskowi. Za dotychczasową współprace między naukowcami i nauczycielami naszych krajów najwyższe odznaczenie - Medal K. Uszyńskiego w imieniu Ukraińskiej Akademii Nauk Pedagogicznych otrzymał przewodniczący KNP Pan prof. dr hab. Bogusław Śliwerski.

Innym wymiarem współpracy, a wynikający z aktywności zespołów zadaniowych przy KNP PAN są następujące jej wymiary:

- Współpraca z Polsko-Czeskim Towarzystwem Naukowym od 2007 roku, zajmującym się m.in. inspirowaniem, prowadzeniem i organizowaniem badań nad historycznymi i współczesnymi problemami Polski i Republiki Czeskiej oraz stosunkami polsko-czeskimi w szerokim kontekście międzynarodowym, ze szczególnym uwzględnieniem ujęć interdyscyplinarnych i porównawczych; współpracą badawczą instytucji, środowisk i osób w Polsce i Republice Czeskiej oraz zabieganiem o jak najszersze wykorzystanie wyników badań naukowych w kształtowaniu politycznych, gospodarczych, kulturalnych i edukacyjnych stosunków polsko-czeskich.

- Stała współpraca naukowa i metodyczna od 1995 roku z Centrum Pedagogicznym dla Szkolnictwa Narodowościowego w Czeskim Cieszynie (Republika Czeska), obejmująca przygotowywanie i prowadzenie warsztatów metodycznych dla nauczycieli, organizowanie naukowych i metodycznych konferencji, aplikowanie i realizowanie grantów pozyskiwanych w ramach konkursów współfinansowanych z Programu Operacyjnego Współpracy Transgranicznej.

- Stała współpraca naukowa od 2009 roku z pracownikami Wydziałów Pedagogicznych Uniwersytetu Mateja Bela w Bańskiej Bystrzycy (Słowacja) oraz Uniwersytetu Ostrawskiego (Republika Czeska) w zakresie m.in. organizowania międzynarodowych konferencji z cyklu „Edukacja małego dziecka", prowadzenia badań w szkołach z polskim językiem nauczania oraz publikowania serii wydawniczych. 
Rozwija się współpraca Zespołu Pedagogiki Chrześcijańskiej z innymi ośrodkami zagranicznymi i poszczególnymi reprezentantami chrześcijańskiej myśli pedagogicznej, której wyrazem jest obecność przedstawicieli tych ośrodków w posiedzeniach Zespołu (zwłaszcza warsztatowych w Kazimierzu Dolnym w miesiącu wrześniu każdego roku). M.in. można wskazać na współpracę z prof. M. Barth McGatrick z Liverpool University (W. Brytania) oraz w ostatnim okresie także bezpośrednie uczestnictwo zagranicznych pedagogów w Warsztatach Zespołu Pedagogiki Chrześcijańskiej w Kazimierzu Dolnym n. Wisłą w roku 2015 r. i w 2016 oraz 2017. Udział w tych warsztatach biorą m.in.: Prof. Raniero Regni z Mediolanu, Prof. Folco Cimagali, Dott. Lorena Menditto, LUMSA - Roma; z Ukrainy Doc. Dr Aleksandra Lysenko, Przykarpacki Narodowy Uniwersytet im. Wasyla Stefanika - Iwano-Frankiwsk, a także Prof. Dr. med. Thomas Hülshoff z Münster i z Hiszpanii. Członkowie Zespołu wchodzą w skład Rady Szkół Katolickich przy Konferencji Episkopatu Polski, są członkami międzynarodowych stowarzyszeń zrzeszających Instytuty i Wydziały Pedagogiki Uniwersytetów Katolickich (Catholic Association of Institutions of Educational Sciences - ACISE), są członkami redakcji czasopism, jak m.in. czasopisma „EducA”, czy personalistycznego „Prosopon. Prospettiva Persona” wydawanego w Teramo we Włoszech, członkami komitetów redakcyjnych czasopism krajowych i zagranicznych.

Współdziałanie z komitetami naukowymi PAN

Prognoz Polska 2000 Plus - udział członków KNP PAN w konferencjach inicjowanych przez czł. honorowego KNP PAN prof. dr hab. Irenę Wojnar.

XI. WSPÓŁPRACA KOMITETU Z ORGANAMI RZĄDOWYMI, SAMORZĄDOWYMI,

INNYMI W ZAKRESIE REPREZENTOWANEJ DYSCYPLINY/ PROBLEMU NAUKOWEGO (OPIS) (NP. WSPÓŁPRACA Z SEJMEM, SENATEM, JEDNOSTKAMI ADMINISTRACJI RZĄDOWEJ, SAMORZĄDU TERYTORIALNEGO, WSPÓŁPRACA Z TOWARZYSTWAMI NAUKOWYMI, Z INNYMI ORGANIZACJAMI).

1. Stała współpraca w składzie Rady Naukowej Rzecznika Praw Dziecka prof. dr hab. Marek Konopczyński, Barbara Smolińska-Theiss.

Współpraca i patronat KNP PAN nad przygotowaniem i przebiegiem III Kongresu Praw Dziecka i VII Międzynarodowej Konferencji Korczakowskiej w Warszawie - wrzesień 2017.

2. Współpraca kierowanego przez prof. M. Zaorską Zespołu Pedagogiki Specjalnej z posłami: Anną Wasilewską, Anną Białkowską, Katarzyną Osos, Pawłem Papke w sprawie projektu rozporządzenia MEN w sprawie szczegółowych kwalifikacji wymaganych od nauczycieli z dnia 22 maja 2017 r.; współpraca z Zespołem ds. opracowania modelu kształcenia uczniów ze 
specjalnymi potrzebami edukacyjnymi, powołanym w MEN (4 członków ZPS KNP PAN wchodzi w skład danego Zespołu: prof. dr hab. Iwona Chrzanowska, prof. dr hab. Kazimiera Krakowiak, prof. dr hab. Grzegorz Szumski, prof. dr hab. Marzenna Zaorska) - Zrządzenie Nr 39 Ministra Edukacji Narodowej z dnia 13 października 2017 r.;

Współpraca z Fundacją „Szansa dla Niewidomych” w sprawie powierzenia Fundacji przez Światową Unię Niewidomych organizacji Międzynarodowej Konferencji International Mobility Conference na temat: „Information resulting in mobility and ability", która planowana jest na 2022 rok oraz aktywny udział ZPS KNP PAN w organizacji przeprowadzeniu danej konferencji;

Współpraca z władzami SOSW w Olsztynie w organizacji jubileuszem 65-lecie Ośrodka.

Współpraca z Polskim Stowarzyszeniem na Rzecz Osób z Niepełnosprawnością Intelektualną w sprawie wsparcia krytycznego stanowiska ZPS na temat projektu rozporządzenia MEN w sprawie szczegółowych kwalifikacji wymaganych od nauczycieli z dnia 22 maja 2017 r. oraz projektu rozporządzenia MEN zmieniającego rozporządzenie w sprawie indywidualnego obowiązkowego rocznego przygotowania przedszkolnego dzieci i indywidualnego nauczania dzieci i młodzieży.

Współpraca z Radą Szkół Katolickich, z Fundacją Lux Vertatis, z Komisją ds. Duchowieństwa Konferencji Episkopatu Polski - Sekcja Stałej Formacji Kapłańskiej - ks. prof. Marian Nowak opracował na zamówienie tej Sekcji opinię w związku z Nowym Ratio Studiorum opublikowanym przez papieża Franciszka w dniu 8 grudnia 2016 r. Opinia została opublikowana jako: Integralność $w$ formacji kaptańskiej. Implikacje i wnioski dla projektów formacyjnych sformułowanych w nowym 'Ratio fundamentalis institutionis sacerdotalis', „Formatio Permanens”. Sekcja Stałej Formacji Kapłańskiej przy Komisji Duchowieństwa Konferencji Episkopatu Polski, Biuletyn Nr 17: Stała formacja kapłanów w świetle nowego 'Ratio Fundamentalis Institutionis Sacerdotalis', Gniezno, Wydawnictwo Gaudentium, nr 17, 2017, s. 31-62.

\section{UZYSKANIE PRZEZ CZŁONKÓW PAN WYSOKICH WYRÓŻNIEŃ AKADEMICKICH W 2017 R.}

1) prof. dr hab. Bogusław Śliwerski (UŁ) został wielokrotnie nagrodzony:

1.1. godność doktora honoris causa Katolickiego Uniwersytetu Lubelskiego Jana Pawła II w Lublinie;

1.2. Nagroda Indywidualna za wybitne osiągnięcia naukowe - przyznana i wręczona w imieniu Rady ds. Szkolnictwa Wyższego i Nauki przy 
Prezydencie Miasta Łodzi Nagroda „Łódzkie Eureka” w 2017 r. Statuetkę „Łódzkie Eureka” otrzymuje indywidualny twórca za wybitne osiągnięcia w poprzednim roku, który został nagrodzony lub wyróżniony na krajowych bądź zagranicznych festiwalach, wystawach, konkursach itp., albo uzyskał nagrodę lub odznaczenia rządowe, resortowe, Polskiej Akademii Nauk itp.

1.3. Medal Im. Księżny Aleksandry Ogińskiej przyznany przez Radę Wydziału Humanistycznego Uniwersytetu Przyrodniczo-Humanistycznego w Siedlcach za całokształt działalności naukowej

1.4. Statuetka - Srebrna Sowa - Społecznej Akademii Nauk w Łodzi za wybitne osiągnięcia naukowe

2) prof. dr hab. Marek Konopezyński - otrzymał najwyższe wyróżnienie Łódzkiego Centrum Doskonalenia Nauczycieli i Kształcenia Praktycznego - „Skrzydła Wyobraźni”

3) prof. dr hab. Zbyszko Melosik - Nagroda JM Rektora za najwyższy wskaźnik efektywności publikacyjnej za 2016 rok

4) prof. dr hab. Agnieszka Cybal-Michalska - Nagroda JM Rektora za działalność organizacyjną

5) prof. dr hab. Agnieszka Gromkowska-Melosik - Nagroda JM Rektora za działalność dydaktyczną

6) prof. dr hab. Maria Czerepaniak-Walczak - Nagroda I stopnia Rektora US za działalność naukową.

7) dr Radosław Nawrocki - Nagroda Rektora UAM za osiągnięcia naukowe w roku 2016.

\section{UWAGI:}

Komitet Nauk Pedagogicznych PAN nie podziela stanowiska Polskiej Akademii Nauk w sprawie odmowy finansowania jedynego czasopisma Komitetu - „Rocznik Pedagogiczny” ze środków DUN (13 pkt,. w wykazie B MNiSW). Złożone $\mathrm{w}$ tej sprawie interpelacje zostały odrzucone przez wiceprezesa PAN. Niszczy ta decyzja 40-letnią tradycję wydawania przez PAN periodyku naukowego polskich pedagogów zrzeszonych w KNP PAN. Członkowie Komitetu są oburzeni brakiem transparentności tej decyzji, arogancją odpowiedzi na odwołanie prezydium KNP PAN oraz całkowitym zlekceważeniem treści odwołania. Oburzający jest brak jakiegokolwiek wsparcia w tej kwestii ze strony Władz Wydziału Nauk Humanistycznych i Społecznych PAN pomimo skierowanego w tej kwestii pisma także członka rzecz. PAN prof. dr. hab. Zbigniewa Kwiecińskiego d.h.c. multi. 